\title{
AMPHIBIANS AND REPTILES FROM ZOLTAN KASZAB'S EXPEDITIONS TO MONGOLIA HELD AT THE HUNGARIAN NATURAL HISTORY MUSEUM
}

\author{
Alberto Sánchez-Vialas ${ }^{1}$, Marta Calvo ${ }^{1}$, Mario García-París ${ }^{1}$ and Judit Vörös ${ }^{2}$ \\ ${ }^{1}$ Museo Nacional de Ciencias Naturales (MNCN-CSIC) \\ cl José Gutiérrez Abascal, 2. 28006, Madrid. Spain \\ E-mails: albertosv90@mncn.csic.es; https://orcid.org/0000-0003-0068-7669; \\ mcalvo@mncn.csic.es; https://orcid.org/0000-0002-8628-1055; \\ mparis@mncn.csic.es; https://orcid.org/0000-0002-9361-9405 \\ ${ }^{2}$ Department of Zoology, Hungarian Natural History Museum, H-1088 Budapest, Baross u. 13, \\ Hungary; E-mail: voros.judit@nhmus.hu; https://orcid.org/0000-0001-9707-1443
}

The amphibians and reptiles collected by Zoltán Kaszab in Mongolia between 1963-1968, deposited in the Collection of Amphibians and Reptiles of the Hungarian Natural History Museum, are reviewed. The 786 studied specimens belong to 15 species (Bufotes pewzowi, Strauchbufo raddei, Rana amurensis, Alsophylax pipiens, Paralaudakia stoliczkana, Phrynocephalus versicolor, P. kulagini, P. hispidus, Eremias argus, E. arguta, E. multiocellata, E. dzungarica, E. przewalskii, Elaphe dione, Gloydius halys) representing 57\% of amphibian and reptile species of Mongolia. Our identification and map representation provide new distribution data for the fitteen species and represent a source of information for the status of the Mongolian herpetofauna in the mid-20th century.

Key words: Central Asia, herpetofauna, Mongolia, Zoltán Kaszab.

\section{INTRODUCTION}

Zoltán Kaszab (1915-1986) (Fig. 1), a world leading specialist in Coleoptera Tenebrionoidea, and director general (1970-1985) of the Hungarian Natural History Museum (HNHM), organized a series of expeditions to Mongolia, in the 1960's decade (KAszAB 1963a, 1965a,b, 1966, 1968b,c, Fig. 1). As a result of these explorations many new species of Tenebrionoidea were described (KAsZAB 1963a, 1964, 1967), but also a number of other organisms were collected as well. Among these is a large collection of amphibians and reptiles held in the HNHM, which have partially been studied until now. DeLy (1979, 1980) described the inter and intraspecific morphological variability among three Eremias species using the specimens collected by Kaszab and published a species list of Kaszab's expeditions.

Mongolian amphibians and reptiles are relatively well known (ANANJEva et al. 1997, Munkhbayar et al. 2001, Terbish et al. 2006). However, total number of records is limited and some groups are carrying on taxonomic problems that need some clarification. This is particularly evident for Phrynocephalus 
Kaup, 1825 (Agamidae) a group still in need of revisionary work (WANG \& Fu 2004, Baravanov \& Ananjeva 2007, Ananjeva et al. 2011).

In this contribution we provide a geographic account of the amphibians and reptiles collected along Kaszab's expeditions to Mongolia with the aim of complementing current available data for the country and to point out taxonomic issues that will require further work. Additionally, we believe Kaszab's materials can be used as a reference point to track changes on current amphibian and reptile distributions as a contribution to Mongolian efforts for Biodiversity Conservation (Suarez \& Tsutsui 2004, Grixti et al. 2009).

\section{MATERIAL AND METHODS}

In the frame of the cooperation between the Hungarian and the Mongolian Academy of Sciences, Zoltán Kaszab led six expeditions to various parts of Mongolia. In the first expedition in 1963 he collected around the capital, Ulanbator, and travelled to the Southeast (reaching the city of Argalant) near the border with China (KaszaB 1963). In 1964 the expedition studied the region southwest of Ulanbator, with special interest on the eastern slopes of Govi-Altai and Changai Mountains (KAszaB 1965a). The third expedition in 1965 covered East Mongolia (KASZAB 1965b), while in 1966 Kaszab visited West Mongolia (Kaszab 1966). In the fifth expedition in 1967 the goal was to access the Transaltai-Govi in

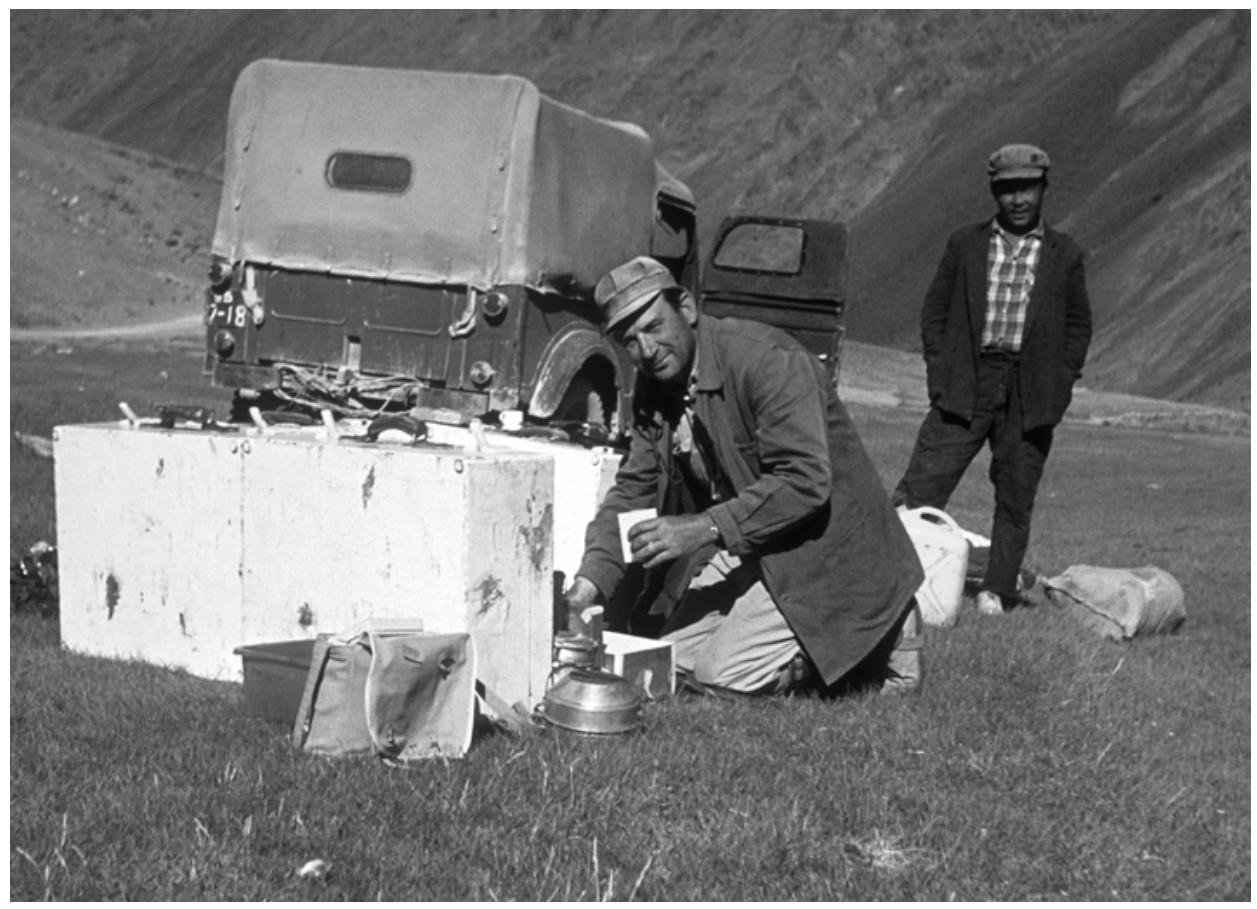

Fig. 1. Zoltán Kaszab in East Mongolia, near Cagan Nuur, during his expedition in June 1968 


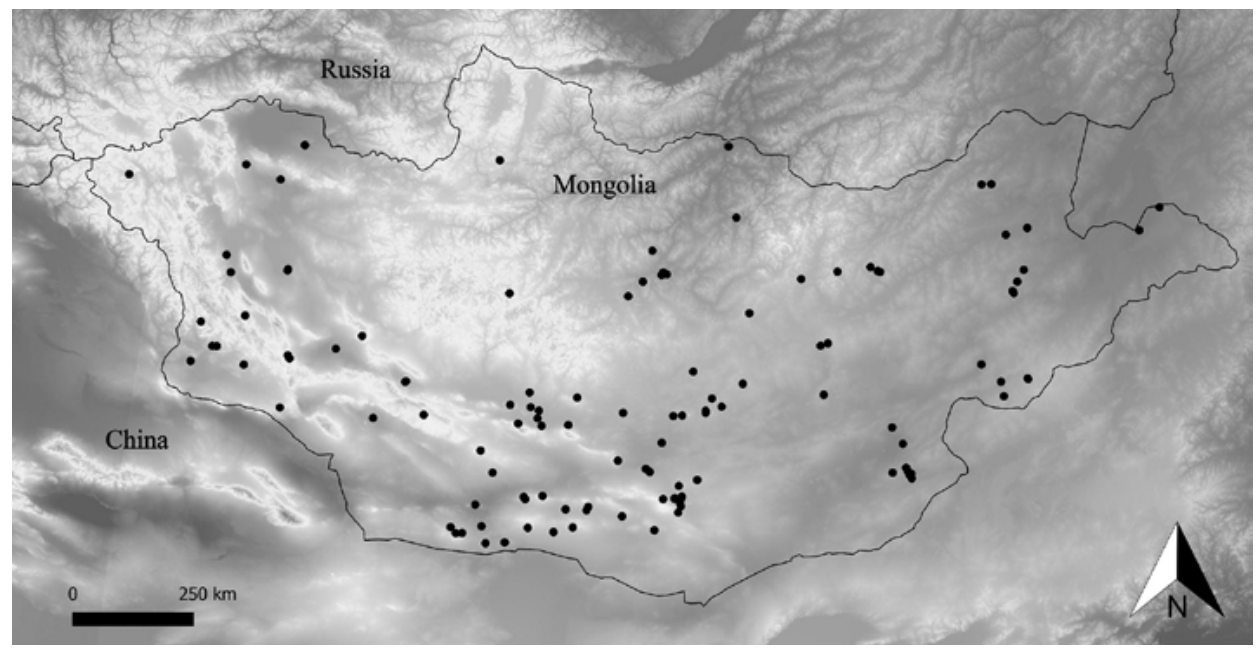

Fig. 2. All localities of amphibians and reptiles collected in Mongolia by Zoltán Kaszab between 1963-1968, and other scientists between 1964-1990

southwestern Mongolia (Kaszab 1968a), and in the last, sixth expedition, he collected in northern and northwestern areas of the country (KASZAB 1968b).

Since the expeditions of Kaszab, the Herpetological Collection of HNHM was enriched with material from Mongolia collected by other scientists (Appendix). In order to give better resolution to the distribution on Mongolian amphibians and reptiles, we included these samples into our summary. Considerable material was kept collected by an expedition labelled as "Z.Z.Syst." represents Zakładu Zoologii Systematycznej, Department of Systematic Zoology, now Institute of Systematics and Evolution of Animals, Polish Academy of Sciences, and that the lizards were found during the Polish-Mongolian Paleontological Expeditions between 1963-1965 (KiELAN-JaworowsKa \& Dovchin 1968). Two of the participants of the expeditions, late Kazimierz Kowalski and Henryk Kubiak collected recent lizards (Magdalena Borsuk-Bialynicka pers. comm.), but we did not find records on how, when and why they were catalogued in HNHM. Most probably these specimens were part of the replacement of the material lost in a fire in 1956, as requests for donation from foreign fellow-institutes (Konsós 2008).

Altogether 786 specimens were studied from the following families: Bufonidae (46), Ranidae (15), Gekkonidae (31), Agamidae (460), Lacertidae (217), Colubridae (6), Viperidae (11). Collection localities are shown in Figure 2.

\section{TAXONOMIC ACCOUNTS}

\section{Bufonidae}

Bufotes Rafinesque, 1815

Systematics of Bufotes remains complicated despite multiple efforts to clarify the situation of Central Asian taxa. Several levels of ploidy, including 
tetraploid populations, have been detected in Asian Bufotes (Bassalayeva et al. 1998, KuZMin 1999, Borkin et al. 2001, Sтӧск et al. 2001, 2005, 2006). Central Asian tetraploid populations have received a variety of denominations through time (Bedriaga 1898, Pisanets \& Shcherbak 1979), which have been extensively reviewed by Sтӧск et al (2001). All examined Mongolian populations of Bufotes are exclusively represented by a tetraploid taxon (Sтӧск et al. 2006, FicEtola \& Sтӧск 2016). According to the priority rule, the name of these populations, currently in use, Bufotes pewzowi (Bedriaga, 1898), should be retained (Ктӧск et al. 2001). Several subspecies of B. pewzowi were tentatively considered valid by SтöcK et al. (2001) (who proposed several nomenclatural acts and perform some lectotype designations), namely B. p. pewzowi [type locality restricted by lectotype designation to Koyar (Pishan), Xinjian, $37^{\circ} 25^{\prime}$ $\mathrm{N}, 77^{\circ} 10^{\prime} \mathrm{E}$ ], B. p. strauchi [type locality restricted by lectotype designation to: Tarim river, Xinjian (about $41^{\circ} \mathrm{N}, 86^{\circ} \mathrm{E}$ )], B. p. taxkorensis [type locality: Taxkurgan $\left(37^{\circ} 40^{\prime} \mathrm{N}, 75^{\circ} 12^{\prime} \mathrm{E}\right), 3120 \mathrm{~m}$ a.s.l. (East Pamirs), Xinjiang, China] and B. $p$. unicolor [type locality: Station Kokmoinok, Chu river valley (about $42^{\circ} 29^{\prime} \mathrm{N}$, $\left.75^{\circ} 51^{\prime} \mathrm{E}\right)$, Kyrgyzstan]. However, a recent phylogeographic study of B. pewzowi from China and Kazakhstan shows incongruences between the clades and the former intraspecific taxonomy: B. p. strauchi and B. p. taxkorensis were synonymized with the nominal subspecies, while B. p. unicolor remains in need of revision (ZHANG et al. 2008).

The HNHM collection holds material from a single population from Western Mongolia (see Fig. 3 and Appendix).

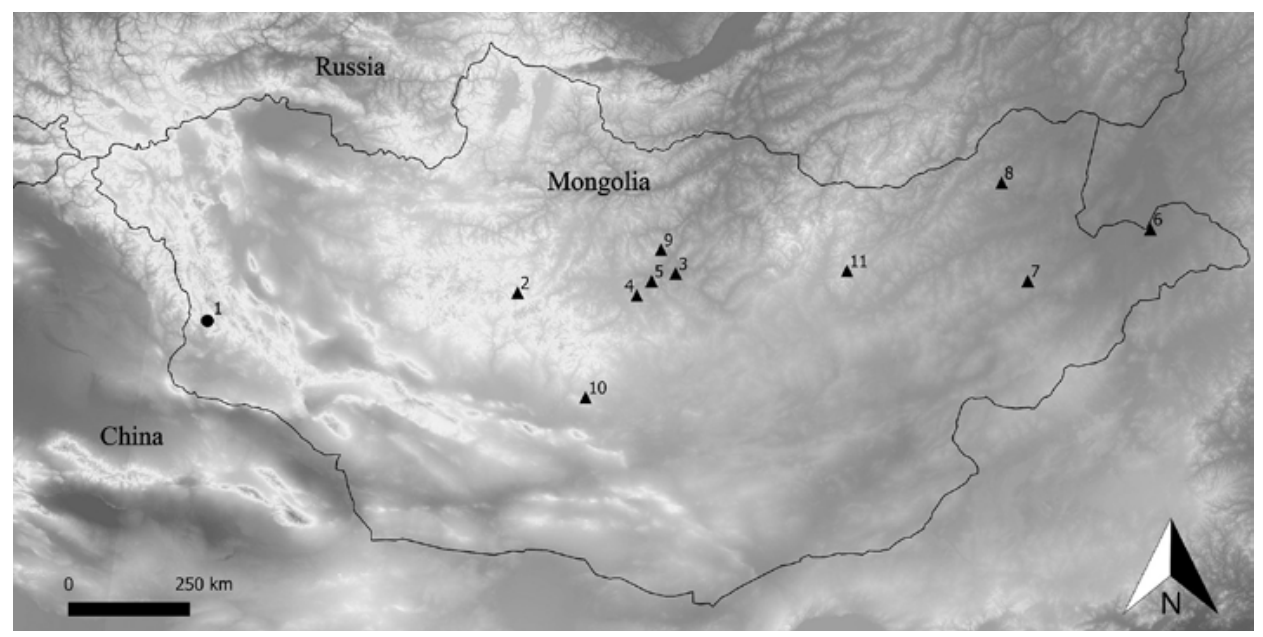

Fig. 3. Localities of Bufonidae. Black dot: Bufotes pewzowi, black triangle: Strauchbufo raddei Numbers (here and later): ID numbers listed in the Appendix 
Strauchbufo Fei, Ye et Jiang, 2012

Represented by a single species, Strauchbufo raddei (Strauch, 1876), described from Ordos and the Alashan Desert [type locality: Alashan Desert, restricted by lectotype designation in Kuzmin \& MasLova (2003)], and widely distributed in Mongolia (BANNiKov 1958, Borkin et al. 1986, KuzMin \& Ischenко 1997, ТеRвish et al. 2006, Sтӧск et al. 2001). The phylogeographic structure of this species was examined across eastern China. Within this region, three clades have been detected (western, central and eastern) that overlap in northern China, close to the Mongolian border (Dong et al. 2012). However, the genetic diversity and also the taxonomic status of Mongolian southernmost populations, which were described as an independent taxon (Bufo koslovi Zarevskij, 1924), need to be reevaluated.

The HNHM collection holds material from 10 localities placed across central and eastern Mongolia, most of them collected by Kaszab (see Fig. 3 and Appendix).

\section{Ranidae}

Rana Linnaeus, 1758

Rana includes two species in Mongolia (Terbish et al. 2006): Rana chensinensis David, 1875, restricted to a narrow zone in the extreme northeast (TERBISH et al. 2006), and Rana amurensis Boulenger, 1886, widely distributed over

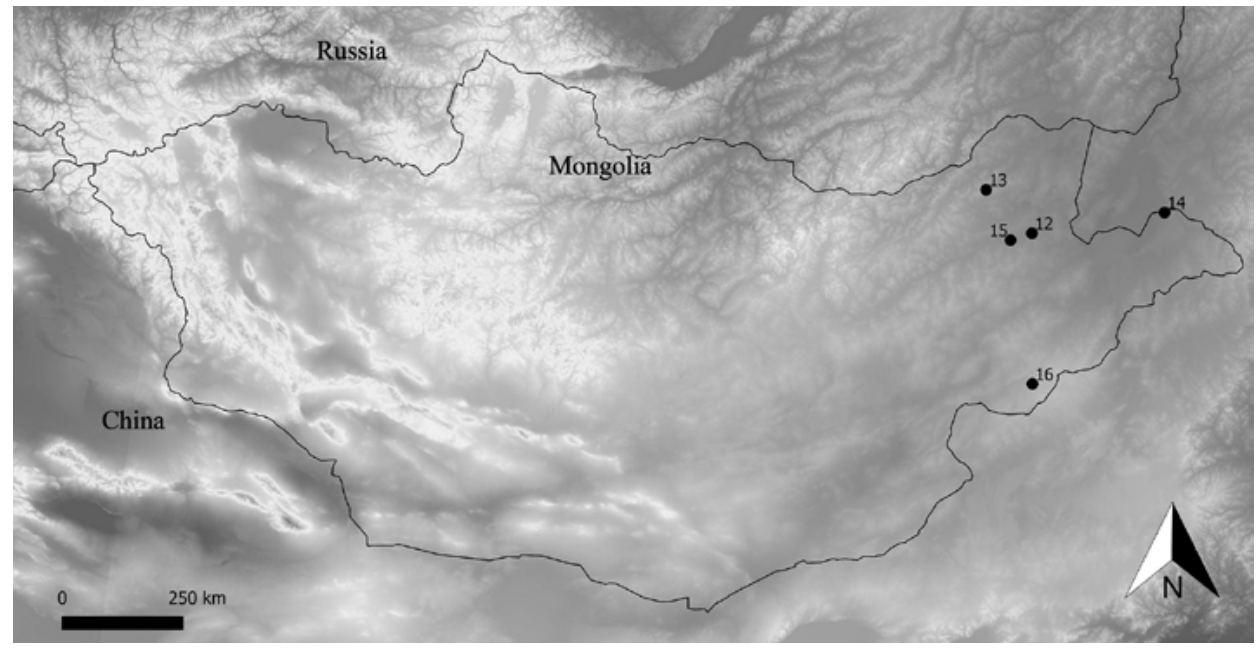

Fig. 4. Localities of Ranidae. Black dot: Rana amurensis 
the north-central and northeastern steppes (Kuzmin 1999). All samples of Rana examined from Kaszab's expeditions correspond to R. amurensis.

According to Kuzmin (1999) the variability within $R$. amurensis is poorly known, and phylogeographic studies are needed to evaluate its geographic variability including populations of the subspecific taxon $R$. amurensis johanseni Kashchenko, 1902 (described as Rana muta johanseni).

There are four specimens within the material collected by Kaszab and 11 specimens collected by other researchers in Mongolia (see Fig. 4 and Appendix).

Our results show Rana amurensis (ID 16) in Dariganga, Sükhbaatar, southeastern Mongolia, where it has not been previously recorded.

\section{Gekkonidae}

Alsophylax Fitzinger, 1843

The genus Alsophylax contains six species distributed across Central Asia (BAUER et al. 2013). Alsophylax pipiens (Pallas, 1814) occurs throughout western Russia and Kazakhstan to north-western China (AnAnjeva \& OrLov 1995). It is the only species of the genus recorded in Mongolia where it is widely distributed, especially in the southern arid zones (SzczerbaK \& Golubev 1986, Ananjeva et al. 1997, Terbish et al. 2006). No phylogeographic studies have been performed of this widely distributed species, and also, no subspecies are known.

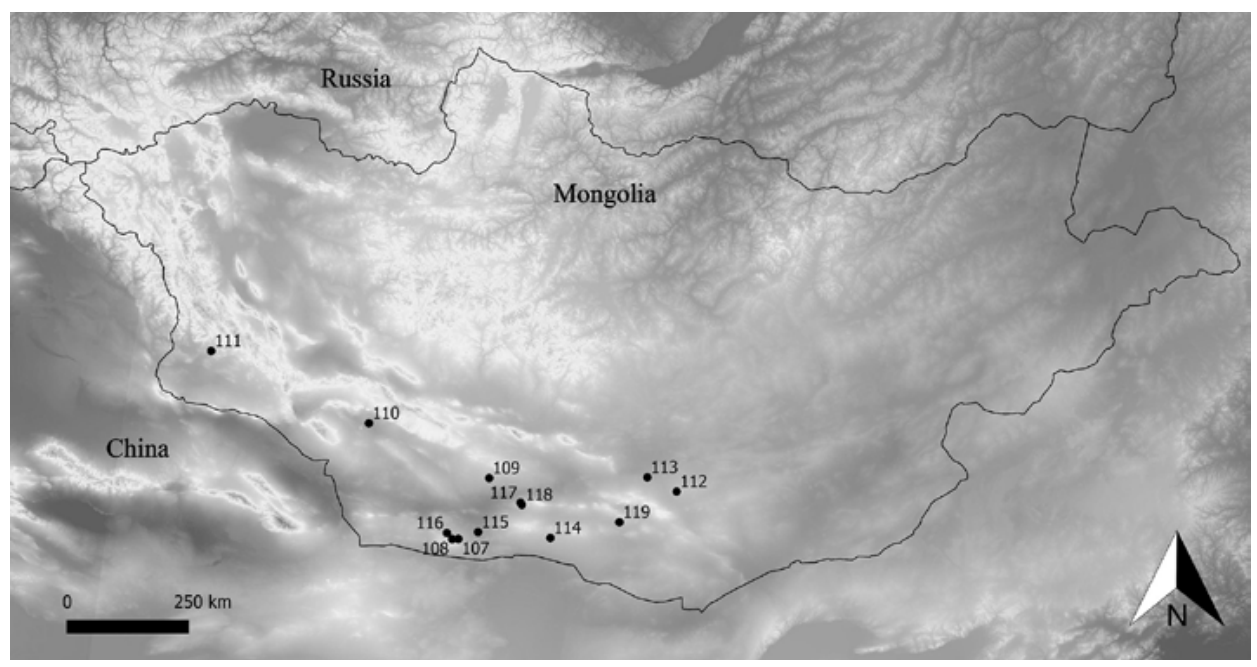

Fig. 5. Localities of Gekkonidae. Black dot: Alsophylax pipiens 
The HNHM collection holds nine jars with specimens collected by Kaszab and four specimens collected by other researchers (see Fig. 5 and Appendix).

\section{Agamidae}

\section{Paralaudakia Baig, Wagner, Ananjeva et Böhme, 2012}

The genus is represented in Mongolia by Paralaudakia stoliczkana (Blanford, 1875) with dispersed populations located in the south-western areas (Ananjeva et al. 1997, Reading et al. 1999, Terbish et al. 2006, Baig et al. 2012). Two subspecies have been described and delimitated by morphological characters: P. s. stoliczkana (Blandford, 1875) and P. s. altaica (Munkhbayar et Shagdarsuren, 1970). Whereas the nominal subspecies occurs in central-southern Mongolia to northern China, P. s. altaica is present in Gobi Altai area (see BAIG et al. 2012). Phylogeographic patterns of both taxa remain unknown.

The HNHM collection presents one jar with one specimen collected by Kaszab and further 7 specimens collected by other researchers (see Fig. 6 and Appendix).

\section{Phrynocephalus Kaup, 1825}

The genus Phrynocephalus is one of the taxonomically most complicated Palaearctic lizard group (Wang \& Fu 2004, Baravanov \& Ananjeva 2007, Macey et al. 2018, Solovyeva et al. 2018). Based on Baravanov and Ananjeva (2007) and AnANjeva et al. (2011), two species of Phrynocephalus are reported for Mongolia: P. (Phrynocephalus) helioscopus (Pallas, 1771), represented by the subspecies $P$. h. varius Eichwald, 1831, only present in the westernmost region of the country; and P. (Phrynocephalus) versicolor Strauch, 1876, a polytypic species with a complex intraspecific taxonomy, which was traditionally represented by two subspecies in Mongolia: $P$. $v$. versicolor, widely distributed over the southern regions and P. v. kulagini Bedriaga, 1909, limited to the northwestern area (Baravanov \& Ananjeva 2007). Previous molecular studies did not include samples from Mongolia (WANG \& Fu 2004), but recently, SolovYEVA et al. (2018) increased the sampling effort including Mongolian populations. As a result of their study, these authors recognized Phrynocephalus kulagini as a full species. Another problematic taxon within the P. versicolor group is $P$. hispidus. It was treated as a synonym of the nominal subspecies since Barabanov and Ananjeva's (2007) catalogue, but according to Dunayev and Poyarkov (2010) and Orlova et al. (2014), it must represent a valid independent subspecific or specific taxon. This problem has been solved by SolovYeva et al. (2018), by recognizing this taxon as a full species Phrynocephalus 
hispidus. Morphological differences between P. versicolor and P. kulagini are mostly based on coloration pattern and scale morphology (BedRIAGA 1909), whereas young and juveniles of Phrynocephalus hispidus possess the tip of the tail white coloured, not black as in the other Mongolian taxa (Dunayev \& Poyarkov 2010, Orlova et al. 2014). The species of the P. versicolor group are parapatrically distributed within Mongolia; the most widespread, $P$. versicolor, occurs across the southeastern region, while the presence of $P$. kulagini is restricted to the north-western region, and P. hispidus to the south-western region of the country.

All specimens of Phrynocephalus studied from the HNHM collection corresponded to $P$. versicolor species group. Most of the material, particularly those from the Southern Govi areas can be assigned to P. v. versicolor (see Appendix). A few other can be assigned to $P$. kulagini based on their coloration and scale patterns and their geographic range, but similar coloration patterns can be found scattered amongst otherwise characteristic $P$. versicolor populations. Tentatively, we assigned the populations placed over the southwestern area of the Dzungaria region to the taxon P. hispidus based on the geographic range of this taxon (OrLova et al. 2014)

The HNHM collection hosts 415 specimens collected by Kaszab and additional 37 specimens collected by other researchers (see Fig. 6 and Appendix).

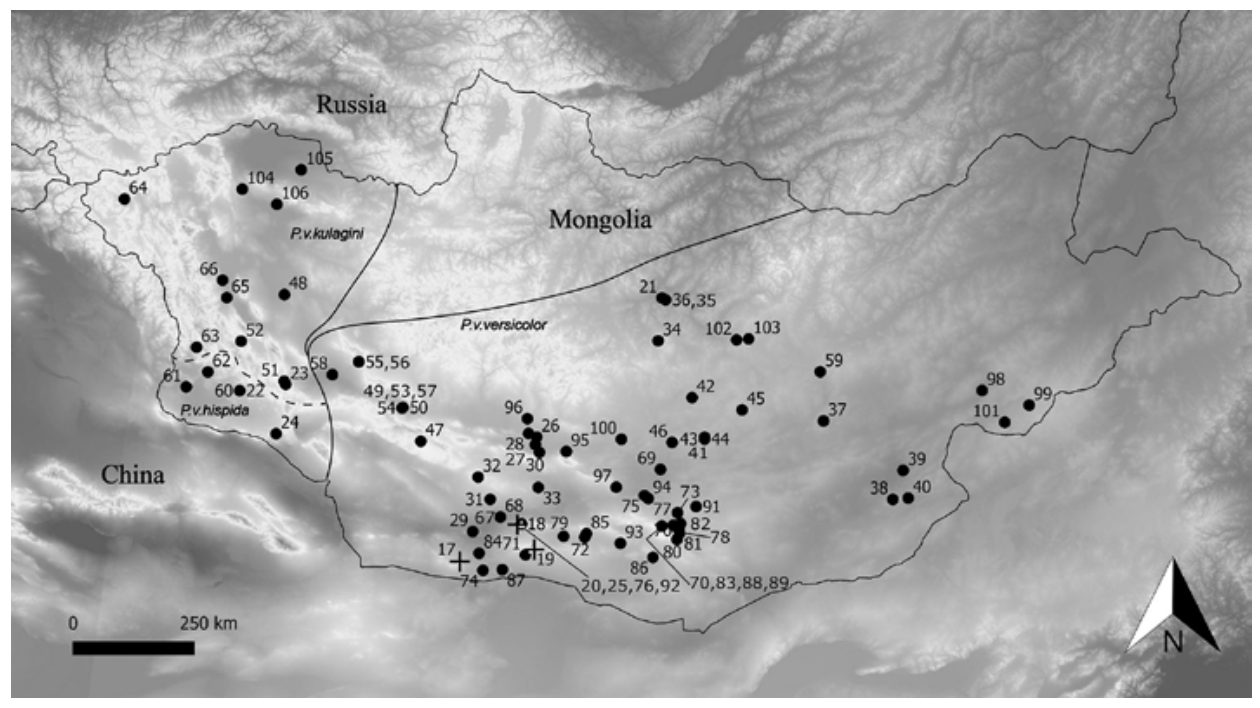

Fig. 6. Localities of Agamidae. Black dots: Phrynocephalus versicolor species group, indicating the species. Dashed line shows putative border between P. hispidus and P. kulagini. Black cross: Paralaudakia stoliczkana 


\section{Lacertidae}

\section{Eremias Fitzinger, 1834}

The diversity of Mongolian Eremias is underestimated (OrLova et al. 2017). Currently, this genus is represented in Mongolia by six described species: Eremias argus Peters, 1869, widely distributed in most of the eastern half of the country with a few isolated populations in western-central areas (MunKHBAyAR 1981, READING et al. 1999, TERBISH et al. 2006) and represented by two subspecies: E. a. argus along the eastern areas, and E. a. barbouri Schmidt, 1925, for the western populations (Ananjeva et al. 1997); Eremias arguta (Pallas, 1773), represented in Mongolia by E. a. potanini Bedriaga, 1912, highly localized in the Dzungarian Govi Desert (Ananjeva et al. 1997, Terbish et al. 2006); Eremias multiocellata Günther, 1872, widely distributed in Mongolia, was formerly represented by E. m. multiocellata Günther, 1872, E. m. bannikowi Szczerbak, 1973, E. m. kozlowi Bedriaga, 1907 and E. m. tsaganbogdensis Munkhabayar \& Borkin, 2010, however, its taxonomic status is complex: (1) Eremias m. tsaganbogdensis, that inhabits the Tsagan Bogde Uul Mountains in southern Mongolia (MunKhbAyAR \& BorKin 2010), is more closely related to E. przewalskii than to E. multiocellata s. str., but further studies are needed to solve its taxonomic status (Orlova et al. 2017), (2) E. m. bannikowi is a junior synomym of $E$. $m$. multiocellata (OrLova et al. 2017), (3) the validity of the taxonomic status of $E$.

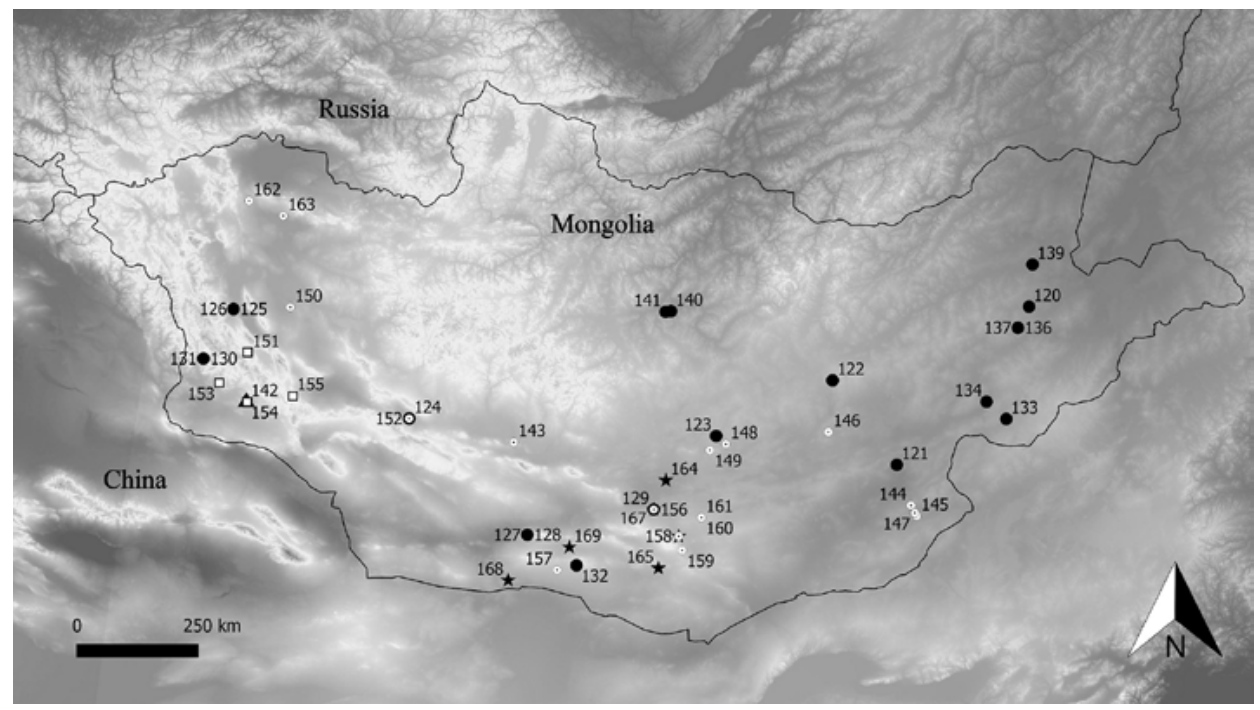

Fig. 7. Localities of Lacertidae. Black dot: Eremias argus, black triangle: E. arguta, white circle with black dot in the middle: E. multiocellata, white square: E. dzungarica, black star: E. przewalski 
m. kozlowi remains unknown as no specimen from the type locality has been studied within a molecular phylogenetic framework (OrLova et al. 2017), and finally (4) the nominotypic subspecies comprises two mitochondrial clades in Mongolia: one corresponding to E. m. multiocellata, distributed over southern and north-western regions, and the other clade (named as "sand form B" by Orlova et al. 2017) distributed over the eastern region (SzCERBAK 1973, 1974, OrLova et al. 2017); Eremias przewalskii (Strauch, 1878), is represented in Mongolia by two non-reciprocally monophyletic clades: one including the most widespread lineage across central and north-western region, corresponding to the nominal subspecies and its junior synonym E. p. tuvensis Szcerbak, 1974, and the other clade, closely related to two undescribed lineages, corresponding to another taxonomic unit distributed over southern Mongolia (ANANJEVA et al. 1997, Rogovin et al. 2001, Terbish et al. 2006, SzcerbaK 1974, Orlova 1992, Orlova et al. 2017). Eremias vermiculata Blandford, 1875, in Mongolia is restricted to southern regions (the Trans Altai Govi and Alashan Govi) with two locations in the Northern Govi (Ananjeva et al. 1997, Terbish et al. 2006). Finally, the recently described E. dzungarica Orlova, Poyarkov, Chirikova, Nazarov, Munkhbaatar, Munkhbayar \& Terbish, 2017, inhabits the rocky areas of the Mongolian Dzungaria (OrLova et al. 2017).

The species represented in HNHM's materials are: E. argus (49), E. multiocellata (123), E. dzungarica (4), E. przewalskii (45) and E. arguta (1) (see Fig. 7 and Appendix).

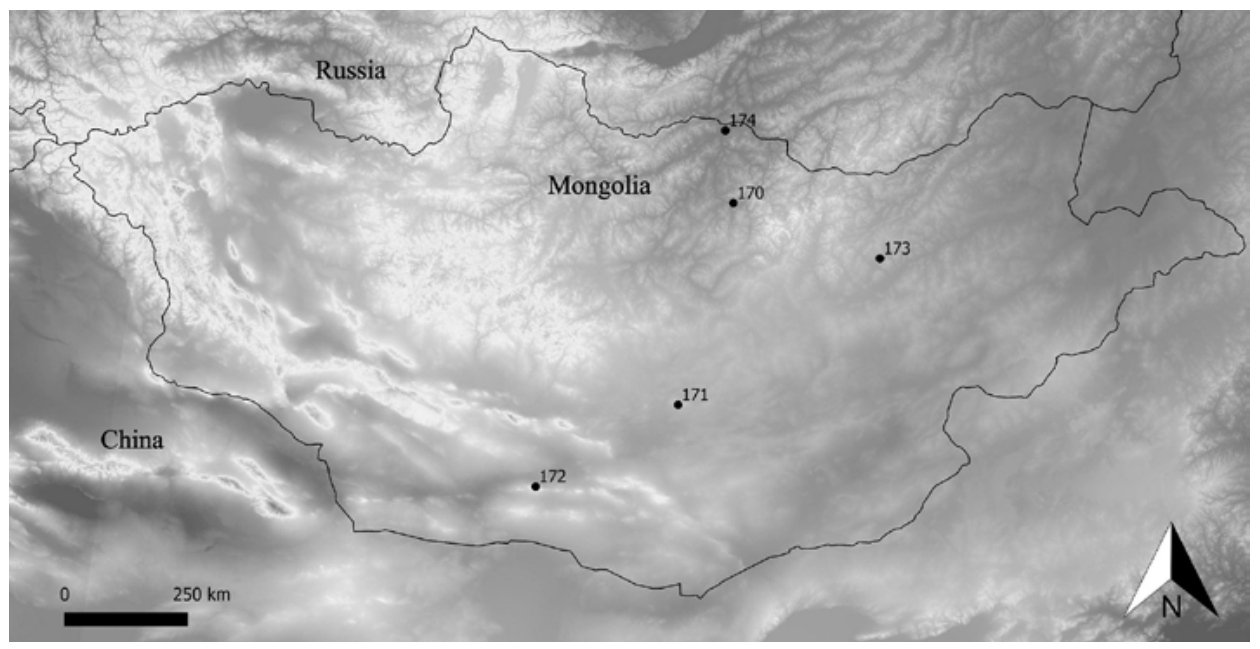

Fig. 8. Localities of Colubridae. Black dot: Elaphe dione 


\section{Colubridae}

Elaphe Fitzinger, 1833

The genus is represented in Mongolia by E. dione (Pallas, 1773) and possibly by E. schrenckii (Strauch, 1873) (ANANJeva et al. 1997, Terbish et al. 2006). Elaphe dione is widely distributed over most of Mongolia (TERBish et al. 2006).

All six specimens collected during Kaszab's expeditions correspond to $E$. dione (see Fig. 8 and Appendix).

\section{Viperidae}

Gloydius Hoge et Romano-Hoge, 1981

Gloydius is represented in Mongolia by two species: G. ussuriensis, which was recently recorded for the east of the country (KROPACHEv et al. 2016) and G. halys (Pallas, 1776), formed by the nominal subspecies G. halys halys, widely distributed over the country, and G. halys stejnegeri (Rendahl, 1933) restricted to the south-eastern region (OrLov \& BARABanov 1999, WAGNER et al. 2016).

Most of the collected specimens of Kaszab's expeditions correspond to G. halys halys, except the specimen ID178, which is located close to the distribution area of $G$. halys stejnegeri (see distribution map in OrLOv \& BARABANOv, 1999), consequently, we herein tentatively assign this specimen to G. halys cf. stejnegeri (see Fig. 9 and Appendix).

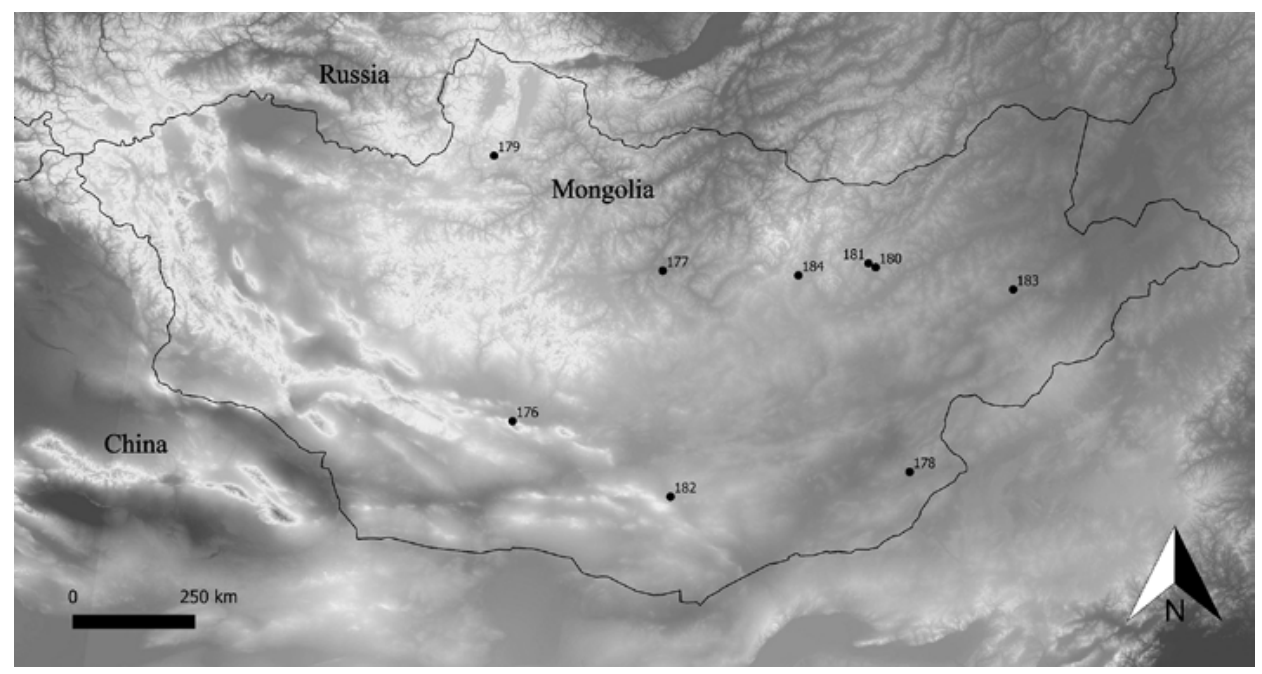

Fig. 9. Localities of Viperidae. Black dot: Gloydius halys 


\section{DISCUSSION}

Fifteen of the 26 native Mongolian amphibian and reptile species (TerBISH et al. 2006, OrLOva et al. 2014, 2017) are represented in HNHM's material. Kaszab's collections did not include Salamandrella keyserlingii Dybowski, 1870, Dryophytes japonicus (Günther, 1859), Rana chensinensis David, 1875, Cyrtopodion elongatus (Blandford, 1875), Teratoscincus przewalskii Strauch, 1887, Phrynocephalus (Phrynocephalus) helioscopus (Pallas, 1771), Eremias arguta (Pallas, 1773), Lacerta agilis Linnaeus, 1758, Zootoca vivipara (Jacquin, 1787), Eryx tataricus (Lichtenstein, 1823), Orientocoluber spinalis (Peters, 1866), Elaphe schrenckii (Strauch, 1873), Natrix natrix (Linnaeus, 1758), Psammophis lineolatus (Brandt, 1838), and Vipera berus (Linnaeus, 1758). However, E. arguta was present in material collected by other scientists.

The presence of Rana amurensis (ID 16) in Dariganga, Sükhbaatar, southeastern Mongolia expands to the south its distribution in Mongolia.

The material tentatively identified by us as Eremias przewalski (Appendix) correspond to at least two different lineages based on the molecular results of OrLova et al. (2017). The ID165 likely correspond to the lineage considered as $E$. cf. przewalski, while ID 168 would correspond to the clade named as " $E$. cf. reticulata" by OrLova et al. (2017). The specific affinities of the other revisited populations remain uncertain; however, ID 167 is geographically close to populations of E. przewalski sensu stricto.

As considered by Orlova et al. (2017), the populations from the Dzungarian region considered as a rock form of E. multiocellata, correspond to a new species recently named as Eremias dzungarica. During our revision, four specimens were assigned to E. dzungarica (collected from two localities close to the type locality of the species) (ID 151, ID153, ID 154, ID155).

Similarly, populations of Phrynocephalus versicolor species group from Dzungarian region, correspond to $P$. hispidus. This taxonomic unit present a distinctive morphology, particularly in the colour pattern of the tail of the juveniles. However, the taxonomic status of the populations collected near the limits of the distribution areas of $P$. kulagini and P. hispidus (ID 51, 52, 23, 63), needs to be confirmed.

Five taxa, namely B. pewzowi, P. helioscopus, P. hispidus, E. arguta and E. dzungarica, are only known in Mongolia from the Dzungarian region, making it an area of particular interest. Only P. helioscopus is not represented among the materials of the HNHM collected from the Dzungarian region.

Historical data provided by series of specimens held in museum collections represent an excellent source of information useful to solve questions about changes of the past species distribution and its biological features and can be used to perform a baseline to study temporal changes and composition of biological communities or local extinctions (Grixtr et al. 2009). 
Acknowledgements - We are grateful to Karen López and Viktória Szőke for their help with the database and specimens, László Peregovits for maps and precising locations, Ottó Merkl for providing literature of Z. Kaszab, and Attila Osi for contacts to paleontologists. Magdalena Borsuk-Bialynicka gave us precious information about the origin of specimens collected by the Polish-Mongolian Paleontological Expedition.

This work was partially supported by project grant CGL2015-66571-P (MINECO/ FEDER, UE) of Spain.

\section{REFERENCES}

Ananjeva, N. B. \& Orlov, N. L. (1995): Communal clutches in Alsophylax pipiens in southern Mongolia. - Russian Journal of Herpetology 2: 142-147.

Ananjeva, N. B., Munkhbayar, K., Orlov, N. L., Orlova, V. F., Semenov, D. V. \& Terbish, K. (1997): Amphibians and reptiles of Mongolia. Reptiles of Mongolia. In: SoкоLov, V. E. (ed.): Vertebrates of Mongolia. - KMK Limited, Moscow, 416 pp.

Ananjeva, N. B., Guo, X. \& WAng, Y. (2011): Taxonomic diversity of agamid lizards (Reptilia, Sauria, Acrodonta, Agamidae) from China: a comparative analysis. - Asian Herpetological Research 2(3): 117-128. https://doi.org/10.3724/SP.J.1245.2011.00117

Baig, K. J., Wagner, P., Ananjeva, N. B., \& Böhme, W. (2012): A morphology-based taxonomic revision of Laudakia Gray, 1845 (Squamata: Agamidae). - Vertebrate Zoology 62(2): 213-260.

Bannikov, A. G. (1958): Data on the fauna and biology of Amphibia and Reptilia in Mongolia. - Bulletin of Moscow Society of Naturalists, Biological Series [Бюлиетень Московского общества испытателей природы, Отдел биологический] 68(2): 71-91.

Barabanov, A. V., \& Ananjeva, N. B. (2007): Catalogue of the available scientific speciesgroup names for lizards of the genus Phrynocephalus Kaup, 1825 (Reptilia, Sauria, Agamidae). - Zootaxa 1399(1): 1-56. https://doi.org/10.11646/zootaxa.1399.1.1

Bassalayeva, S. A., Kolbintzev, V. G., Dujsebayeva, T. N \& Castellano, S. (1998): Notes on the distribution and natural history of the Middle Asiatic toad (Bufo danatensis) from the Aksu-Dzhabagly Nature Reserve, Western Tien-Shan Mountains. - Advances in Amphibian Research in the Former Soviet Union 3: 163-177.

Bedriaga, J. V. (1898): Amphibien und Reptilien. Pp. 1-69. In: Wissenschaftliche Resultate der von N. M. Przewalski nach Central-Asien unternommenen Reisen. Vol. 3. Lieferung 1. Zoologischer Theil. - St Petersburg, Akademie der Wissenschaften.

Bedriaga, J. V. (1909): Amphibien und Reptilien. Pp. 279-502. In: Wissenschaftliche Resultate der von N. M. Przewalski nach Central-Asien unternommenen Reisen. Vol. 3. Lieferung 3. Zoologischer Theil. - St Petersburg, Akademie der Wissenschaften.

Borkin, L.Y. \& Semenov, D. V. (1986): The temperature and the daily activity in the motley round-headed lizard, Phrynocephalus versicolor (Reptilia, Agamidae), in the Trans Altai Gobi Desert. - Zoologicheskii Zhurnal 65(11): 1655-1663.

Borkin, L. J., Eremchenko, V. K., Helfenberger, N., PAnfilov, M. \& Rosanov, J. M. (2001): On the distribution of diploid, triploid and tetraploid green toads (Bufo viridis complex) in south-eastern Kazakhstan. - Russian Journal of Herpetology 8(1): 45-53.

Borkin, L., Terbish, Kh. \& Tsaune, I. A. (1986): Tetraploid and diploid populations of toad of the Bufo viridis group from Mongolia. - Doklady Akademii Nauk SSSR 287(3): 760764 . 
Dely, O. Gy. (1979): Analyse der morphologischen Eigentümlichkeiten drei mongolischer Eremias-Arten. - Vertebrata Hungarica 19: 3-84.

Dely, O. Gy. (1980): Die variabilität von drei Eremias-Arten aus der Mongolei. - Acta Zoologica Academiae Scientiarum Hungaricae 26: 89-122.

Dong, B., Che, J., Ding, L., Huang, S., Murphy, R. W., Zhao, E. \& Zhang, Y. (2012): Testing hypotheses of Pleistocene population history using coalescent simulations: refugial isolation and secondary contact in Pseudepidalea raddei (Amphibia: Bufonidae). Asian Herpetological Research 3: 103-113. https://doi.org/10.3724/SP.J.1245.2012.00103

Dunayev, E. A. \& Poyarkov, N. A. (2010): Phylogeny, phylogeography and identification of Asian toad-headed agamas Phrynocephalus (superspecies versicolor). - Current Studies in Herpetology 10(3-4): 142-143.

Ficetola, G. F., \& Stöcк, M. (2016): Do hybrid-origin polyploid amphibians occupy transgressive or intermediate ecological niches compared to their diploid ancestors? Journal of Biogeography 43(4): 703-715. https://doi.org/10.1111/jbi.12667

Grixti, J. C., Wong, L. T., Cameron, S. A. \& Favret, C. (2009): Decline of bumble bees (Bombus) in the North American Midwest. - Biological Conservation 142(1): 75-84. https://doi.org/10.1016/j.biocon.2008.09.027

Kaszab, Z. (1963a): Ergebnisse der zoologischen Forschungen von Dr. Z. Kaszab in der Mongolei. 2. Liste der Fundorten. - Folia entomologica hungarica 16: 285-315.

Kaszab, Z. (1963b): Angaben zur Kentniss der Tenebrioniden-Fauna der Mongolischen Volksrepublik (Coleoptera). - Acta Zoologica Academiae Scientiarum Hungaricae 11: 295-346.

KaszaB, Z. (1964): Beiträge zur Kentniss der Tenebrioniden-Fauna des Mittelen Teiles der Mongolischen Volksrepublik (Coleoptera). - Acta Zoologica Academiae Scientiarum Hungaricae 10: 363-404.

KAsZAB, Z. (1965a): Ergebnisse der zoologischen Forschungen von Dr. Z. Kaszab in der Mongolei. 25. Liste der Fundorte der II. Expedition. - Folia entomologica hungarica 18: 5-38.

Kaszab, Z. (1965b): Ergebnisse der zoologischen Forschungen von Dr. Z. Kaszab in der Mongolei. 107. Liste der Fundorte der IV. Expedition. - Folia entomologica hungarica 18: 587-623.

KaszaB, Z. (1966): Ergebnisse der zoologischen Forschungen von Dr. Z. Kaszab in der Mongolei. 66. Liste der Fundorte der III. Expedition. - Folia entomologica hungarica 19: 569-620.

Kaszab, Z. (1967): Die Tenebrioniden der Westmongolei (Coleoptera). - Acta Zoologica Academiae Scientiarum Hungaricae 13: 279-351.

KAszAB, Z. (1968a): Ergebnisse der zoologischen Forschungen von Dr. Z. Kaszab in der Mongolei. 168. Tenebrionidae (Coleoptera). - Acta Zoologica Academiae Scientiarum Hungaricae 14: 339-397.

KAsZAB, Z. (1968b): Ergebnisse der zoologischen Forschungen von Dr. Z. Kaszab in der Mongolei. 152. Liste der Fundorte der V. Expedition. - Folia entomologica hungarica 21: $1-44$.

Kaszaв, Z. (1968c): Ergebnisse der zoologischen Forschungen von Dr. Z. Kaszab in der Mongolei. 186. Liste der Fundorte der VI. Expedition. - Folia entomologica hungarica 21: 389-444.

Korsós, Z. (2008): History of the Herpetological Collection of the Hungarian Natural History Museum. - Annales historico-naturales Musei nationalis hungarici 100: 37-93. 
Kropachev, I. I., Orlov, N. L. \& Orlova, V. F. (2016): Gloydius ussuriensis (Emelianov, 1929) (Serpentes: Viperidae: Crotalinae). A new snake species for the herpetofauna of Mongolia. - Russian Journal of Herpetology 23: 108-114.

Kuzmin, S. L. (1999): The amphibians of the former Soviet Union. - Pensoft Series Faunistica 12, Sofia, Moscow, 538 pp.

Kuzmin, S. L., \& Maslova, I. V. (2003): Amphibians of the Russian Far East. Vol. 8. Advances in Amphibian Research in the Former Soviet Union - Pensoft Publisher, Sofia, Moscow, 462 pp.

Kuzmin, S. L. \& Ischenкo, V. G. (1997): Skeletochronology of Bufo raddei from Gobi Desert. - Journal of Herpetology 31(2): 306-309. https://doi.org/10.2307/1565404

Macey, J. R., Schulte, J. A., Ananjeva, N. B., Dyke, E. T., Wang, Y., Orlov, N., Shafiei, S., Robinson, M. D., Dujsebayeva, T., Freund, G. S., Fischer, C. M., Liu, D. \& Papenfuss, T. J. (2018): A molecular phylogenetic hypothesis for the Asian agamid lizard genus Phrynocephalus reveals discrete biogeographic clades implicated by plate tectonics. - Zootaxa 4467(1): 1-81.

Munkhbayar, KH. (1981): New data on the distribution of some amphibians and reptiles in Mongolia. - Trudy Zoologicheskogo Instituta 101: 52-56.

Munkhbayar, Kh., Terbish, Kh. \& Munkhbaatar, M. (2001): A guide to the amphibians and reptiles of Mongolia. - Ulaanbaatar, Hiimori, 52 pp.

Munkhbayar, KH. \& Borkin, L. J. (2010): A new subspecies of the lizard Eremias multiocellata tsaganbogdensis subsp. nov. (Lacertidae) from Southern Mongolia. - Izvestia Samarskogo nauchnogo tsentra Rossiyskoy Akademii Nauk 12(1): 122-124.

OrLova, V. F. (1992): Intrapopulational and geographic variation of Eremias przewalskii Stauch in Mongolia. - Asiatic Herpetological Research 4: 113-122.

Orlova, V. F., Dunaev, E. A., Nazarov, R. A., Terbish, K. \& Erdentushig, P. (2014): Materials on the south-western Mongolia herpetofauna. - Current Studies in Herpetology 14(1-2): 32-43.

Orlova, V. F., Poyarkov, N. A., Chirikova, M. A., Nazarov, R. A., Munkhbayar, M., Munkhbayar, K. H., \& Terbish, K. H. (2017): MtDNA differentiation and taxonomy of Central Asian racerunners of Eremias multiocellata-E. przewalskii species complex (Squamata, Lacertidae). - Zootaxa 4282(1): 1-42. https://doi.org/10.11646/zootaxa .4282.1.1

Orlov, N. L., \& Barabanov, A. V. (1999): Analysis of nomenclature, classification, and distribution of the Agkistrodon halys-Agkistrodon intermedius complexes: a critical review. - Russian Journal of Herpetology 6(3): 167-192.

Pisanets, E. M., \& Shcherbak, N. N. (1979): Sistematika zelenykh zhab (Amphibia, Anura) fauny SSSR. - Vestnik Zoologii 4: 11-16. [in Russian]

Reading, R. P., Amgalanbaatar, S. \& Lhagvasuren, L. (1999): Biological assessment of three beauties of the Gobi National Conservation Park, Mongolia. - Biodiversity and Conservation 8: 1115-1137. https://doi.org/10.1023/A:1008900427566

Rogovin, K. A., Semenov, D. V. \& Shenbrot, G. I. (2001): Lizards of the northern Mongolian deserts: Densities and community structure. - Asiatic Herpetological Research 9: 1-9.

Solovyeva, E. N., Lebedev, V. S., Dunayev, E. A., Nazarov, R. A., Bannikova, A. A., Che, J., Murphy, R. W \& Poyarkov, N. A. (2018): Cenozoic aridization in Central Eurasia shaped diversification of toad-headed agamas (Phrynocephalus; Agamidae, Reptilia). - PeerJ 6e: 4543.

Stöck, M., Ustinova, J., Lamatsch, D. K., Schartl, M., Perrin, N. \& Moritz, C. (2010): A vertebrate reproductive system involving three ploidy levels: hybrid origin of trip- 
loids in a contact zone of diploid and tetraploid Palearctic green toads (Bufo viridis subgroup). - Evolution 64(4): 944-959. https://doi.org/10.1111/j.1558-5646.2009.00876 .$x$

Stöck, M., Bretschneider, P. \& Grosse, W. (2001): The mating call and male release call of Bufo raddei Strauch, 1876 with some phylogenetic implications. - Russian Journal of Herpetology 7(3): 215-226.

Stöck, M., Steinlein, C., Lamatsch, D. K., Schartl, M. \& Schmid, M. (2005): Multiple origins of tetraploid taxa in the Eurasian Bufo viridis subgroup. - Genetica 124: 255-272. https://doi.org/10.1007/s10709-005-3085-9

Stöck, M., Moritz, C., Hickerson, M., Frynta, D., Dujsebayeva, T., Eremchenko, V., MacEY, J. R., PApenfuss, T. J. \& WAKE, D. B. (2006): Evolution of mitochondrial relationships and biogeography of Palearctic green toads (Bufo viridis subgroup) with insights in their genomic plasticity. - Molecular Phylogenetics and Evolution 41: 663-689. https://doi.org/10.1016/j.ympev.2006.05.026

Stöck, M., Grifoni, G., Armor, N., Scheidt, U., Sicilia, A. \& Novarini, N. (2016): On the origin of the recent herpetofauna of Sicily: comparative phylogeography using homologous mitochondrial and nuclear genes. - Zoologischer Anzeiger-A Journal of Comparative Zoology 261: 70-81. https://doi.org/10.1016/j.jcz.2015.10.005

Suarez, A. V. \& Tsutsui, N. D. (2004): The value of museum collections for research and society. - BioScience 54 (1): 66-74. https://doi.org/10.1641/0006-3568(2004)054[0066: TVOMCF]2.0.CO;2

Szczerbak, N. N. \& Golubev, M. L. (1986): Gecko fauna of the USSR and contiguous regions. - Society for the Study of Amphibians and Reptiles. [In Russian, English version published in 1996]

Terbish, Kh., Munkhbayar, Kh., Clark, E. L., Munkhbat, J., Monks, E. M., Munkhbaatar, M., Baillie, J. E. M., Borkin, L., Batsaikhan, N., Samiya, R. \& Semenov, D. V. (2006): Mongolian Red List of Reptiles and Amphibians. Vol. 5. Regional Red List Series - Zoological Society of London, London.

Wagner, P., Tiutenko, A., Mazepa, G., Borkin, L. J. \& Simonov, E. (2016): Alai! Alai!-a new species of the Gloydius halys (Pallas, 1776) complex (Viperidae, Crotalinae), including a brief review of the complex. - Amphibia-Reptilia 37(1): 15-31. https://doi.org/10 $.1163 / 15685381-00003026$

WANG, Y. \& FU, J. (2004): Cladogenesis and vicariance patterns in the toad-headed lizard Phrynocephalus versicolor species complex. - Copeia 2: 199-206. https://doi.org/10 .1643/CG-03-082R1

ZarevskiJ, S. F. (1924): On a new species of Bufo from South Mongolia. - Annuaire du Musée Zoologique de l'Académie des Sciences de Leningrad 25: 152-154.

Zhang, Y. J., Stöck, M., Zhang, P., Wang, X. L., Zhou, H. \& Qu, L. H. (2008): Phylogeography of a widespread terrestrial vertebrate in a barely-studied Palearctic region: green toads (Bufo viridis subgroup) indicate glacial refugia in Eastern Central Asia. - Genetica 134(3): 353-365. https://doi.org/10.1007/s10709-008-9243-0

Received October 30, 2018, accepted March 5, 2019, published May 31, 2019 


\section{APPENDIX}

Date of collection, collector, geographic coordinates, locality details and number of collected specimens (NS) for the entire dataset from Mongolia hosted by the Collection of Amphibians and Reptiles of the Hungarian Natural History Museum.

\section{BUFONIDAE}

Bufotes pewzowi (Bedriaga, 1898)

ID 1: 1966.07.06. leg. Kaszab Z. $46.5^{\circ} \mathrm{N}, 91.54^{\circ} \mathrm{E}$, Mongol Altaj Mts., Uljasutajn gol, $45 \mathrm{~km}$ NNW of Somon Bulgan, Khovd; NS: 3

Strauchbufo raddei (Strauch, 1876)

ID 2: 1966.06.19. leg. Kaszab Z. $47.49^{\circ} \mathrm{N}, 99.93^{\circ} \mathrm{E}$, Changaj Mts., $8 \mathrm{~km}$ W of Somon IkhTamir, Arkhangai; NS: 2

ID 3: 1968.07.24. leg. Kaszab Z. $47.84^{\circ} \mathrm{N}, 104.31^{\circ} \mathrm{E}, 11 \mathrm{~km}$ W of Somon Bayanuur, Bulgan; NS: 15

ID 4: 1968.07 .23 . leg. Kaszab Z. $47.44^{\circ} \mathrm{N}, 103.22^{\circ} \mathrm{E}$, SW of Somon Daschinchilen, Bulgan; NS: 1

ID 5: 1966.07.21-22. leg. Kaszab Z. $47.71^{\circ} \mathrm{N}, 103.64^{\circ} \mathrm{E}, 9 \mathrm{~km}$ E of Somon Abzaga, Bulgan; NS: 6 ID 6: 1965.08 .11 . leg. Kaszab Z. $47.64^{\circ} \mathrm{N}, 117.49^{\circ} \mathrm{E}$, SW corner of Lake Bujr, Dornod; NS: 1

ID 7: 1970.07.31. leg. Beregi Zs. $47.1^{\circ} \mathrm{N}, 113.95^{\circ} \mathrm{E}, 80 \mathrm{~km}$ SW of Cojbalsan, Dornod; NS: 12

ID 8: 1965.08 .17 . leg. Kaszab Z. $48.97^{\circ} \mathrm{N}, 113.65^{\circ} \mathrm{E}, 15 \mathrm{~N}$ of Galuut, Somon Tsagaan-Ovoo, Dornod; NS: 1

ID 9: 1965.08.17. leg. Kaszab Z. $48.29^{\circ} \mathrm{N}, 103.92^{\circ} \mathrm{E}, 53 \mathrm{~km}$ NW of Cojbalsan, Dornod; NS: 2

ID 10: 1965.08.19. leg. Kaszab Z. $45.54^{\circ} \mathrm{N}, 101.81^{\circ} \mathrm{E}, 20 \mathrm{~km}$ SW of Somon Norovlin, Khentii; NS: 2

ID 11: 1965.07.26. leg. Kaszab Z. 47.69² N, 109.07E, Somon Bayandelger, Töv; NS: 1

\section{RANIDAE}

Rana amurensis Boulenger, 1886

ID 12: 1976.08.11. leg. Kiss I. $48.06^{\circ} \mathrm{N}, 114.46^{\circ} \mathrm{E}$, Cojbalsan, Dornod; NS: 1

ID 13: 1965.08 .18 . leg. Kaszab Z. $48.99^{\circ}$ N, $113.38^{\circ} \mathrm{E}, 32 \mathrm{~km}$ SE of Somon Bayan-uul, Dornod; NS: 1

ID 14: 1965.08.13-14. leg. Kaszab Z. $47.98^{\circ}$ N, $118.16^{\circ}$ E, Somon Khalkhgol, Dornod; NS: 3

ID 15: 1970.08 .01 . leg. Beregi Zs. $47.99^{\circ} \mathrm{N}, 113.84^{\circ} \mathrm{E}, 8 \mathrm{~km} \mathrm{~W}$ of Somon Bulgan, floodplain of Kherlen, Dornod; NS: 1

ID 16: 1972.08.20. leg. Mészáros F. $45.29^{\circ} \mathrm{N}, 113.84^{\circ} \mathrm{E}$, Dariganga, Sükhbaatar; NS: 9

\section{GEKKONIDAE}

Alsophylax pipiens (Pallas, 1827)

ID 107: 1967.06.25-26. leg. Kaszab Z. $42.95^{\circ} \mathrm{N}, 98.87^{\circ} \mathrm{E}, 13 \mathrm{~km}$ E of Caganbulag border control, Mt. Cagan Bogd, Toorojn bulag spring, Bayankhongor; NS: 2

ID 108: 1967.06.24. leg. Kaszab Z. $42.95^{\circ}$ N, $98.71^{\circ} \mathrm{E}$, Caganbulag border control, Mt. Cagan Bogd, Bayankhongor; NS: 3

ID 109: 1967.06.29. leg. Kaszab Z. $44.11^{\circ}$ N, $99.61^{\circ}$ E, Dzun Mod Oazis, 100 km S of Somon Shinejinst, Bayankhongor; NS: 1 
ID 110: 1966.06.28. leg. Kaszab Z. $45.02^{\circ} \mathrm{N}, 96.39^{\circ} \mathrm{E}$, Zachuj Gobi, $10 \mathrm{~km}$ N of Lake Buur, Govi-Altai; NS: 1

ID 111: 1966.07.04. leg. Kaszab Z. $46.08^{\circ} \mathrm{N}, 92.04^{\circ} \mathrm{E}, 5 \mathrm{~km}$ NE of Somon Üyench, Khovd; NS: 1

ID 112: 1964.06.19. leg. Kaszab Z. $43.86^{\circ} \mathrm{N}, 104.46^{\circ} \mathrm{E}, 25 \mathrm{~km}$ N of Somon Bulgan, Ömnögovi; NS: 11

ID 113: 1965.06.03. leg. Z.Z.Syst. $44.13^{\circ} \mathrm{N}, 103.72^{\circ} \mathrm{E}$, Bayan Zag, Bulgan, Ömnögovi; NS: 1

ID 114: 1990.05.13. leg. Fábián Gy., Hreblay M., leg. Peregovits L., Ronkay G. $43.01^{\circ} \mathrm{N}$, $101.21^{\circ} \mathrm{E}$, Nojon Mts., $22 \mathrm{~km}$ SE of Gurvantes, Ömnögovi; NS: 1

ID 115: 1967.06.20. leg. Kaszab Z. 43.1 ${ }^{\circ}$ N, $99.36^{\circ}$ E, Nojon Mts., Ovot Chural border control, at the ruins of Lama monastery, Ömnögovi; NS: 2

ID 116: 1967.06.21. leg. Kaszab Z. $43.06^{\circ} \mathrm{N}, 98.57^{\circ} \mathrm{E}$, Nojon Mts., $64 \mathrm{~km} \mathrm{~W}$ of Ovot Chural border control, at the Muchor örege river, Ömnögovi; NS: 4

ID 117: 1965.06.12. leg. Z.Z.Syst. $43.66^{\circ} \mathrm{N}, 100.43^{\circ} \mathrm{E}$, Altan Mts., Ömnögovi; NS: 1

ID 118: 1964.06 .14 . leg. Z.Z.Syst. $43.62^{\circ} \mathrm{N}, 100.47^{\circ} \mathrm{E}$, Naran Bulag, Altan Mts., Ömnögovi; NS: 1

ID 119: 1967.06.16. leg. Kaszab Z. 43.31N N, $102.98^{\circ}$ E, East Mt. Zöölön, 58 km SW of Somon Sevrei , Ömnögovi; NS: 2

\section{AGAMIDAE}

Paralaudakia stoliczkana (Blanford, 1875)

ID 17: 1967.06.24. leg. Kaszab Z. $42.95^{\circ}$ N, $98.87^{\circ}$ E, Mt. Cagan Bogd, Toorojn bulag source, Bayankhongor; NS: 1

ID 18: 1965.05.22. leg. Z.Z.Syst. $43.66^{\circ} \mathrm{N}, 100.43^{\circ} \mathrm{E}$, Altan Mts., Gurvantes, Ömnögovi; NS: 1

ID 19: 1965.08 . leg. Kubiak H., Z.Z.Syst. $43.2^{\circ}$ N, $100.71^{\circ} \mathrm{E}$, Altan Mts., Nemegt Valley, Gurvantes, Ömnögovi; NS: 2

ID 20: 1965.06 .12 . leg. Z.Z.Syst. $43.66^{\circ} \mathrm{N}, 100.43^{\circ} \mathrm{E}$, Altan Mts., Gurvantes, Ömnögovi; NS: 4

Phrynocephalus versicolor Strauch, 1876 species group

ID 21: 1964.07.03. leg. Kaszab Z. $47.88^{\circ} \mathrm{N}, 104.22^{\circ} \mathrm{E}$, S of Bajan Lake, Bulgan; NS: 5

ID 22: 1990.05.15. leg. Fábián Gy., Hreblay M., Peregovits L., Ronkay G. $45.8^{\circ} \mathrm{N}, 92.83^{\circ} \mathrm{E}$, Dzsungar Gobi, $60 \mathrm{~km}$ E of Altay somon centre, Khovd; NS: 1

ID 23: 1966.07.02. leg. Kaszab Z. $46^{\circ} \mathrm{N}, 94.03^{\circ} \mathrm{E}$, Somon Altaj, on the left side of River Bodonchi, Khovd; NS: 6

ID 24: 1966.06.30. leg. Kaszab Z. $45.07^{\circ} \mathrm{N}, 93.91^{\circ} \mathrm{E}$, Tachijn Schar Mts., $40 \mathrm{~km} \mathrm{NW}$ of Mt Bogd Valley, Govi-Altai; NS: 2

ID 25: 1965.06.12. leg. Z.Z.Syst. $43.66^{\circ} \mathrm{N}, 100.43^{\circ} \mathrm{E}$, Altan Mts., Ömnögovi; NS: 1

ID 26: 1964.06 .25 . leg. Kaszab Z. $45.29^{\circ} \mathrm{N}, 100.79^{\circ} \mathrm{E}, 10 \mathrm{~km}$ N of Somon Bogd, Bayankhongor; NS: 2

ID 27: 1964.06.24. leg. Kaszab Z. $45.15^{\circ} \mathrm{N}, 100.76^{\circ} \mathrm{E}, 5 \mathrm{~km} \mathrm{~S}$ of Somon Bogd, Bayankhongor; NS: 1

ID 28: 1964.06 .25 . leg. Kaszab Z. $45.36^{\circ} \mathrm{N}, 100.57^{\circ} \mathrm{E}, 8 \mathrm{~km}$ S of Somon Zinst, Bayankhongor; NS: 1

ID 29: $1967.06 .26-27$. leg. Kaszab Z. $43.5^{\circ} \mathrm{N}, 99.18^{\circ} \mathrm{E}, 71 \mathrm{~km} \mathrm{~N}$ of Caganbulag, Bayankhongor; NS: 5

ID 30: 1964.06 .23 . leg. Kaszab Z. $45.01^{\circ}$ N, $100.87^{\circ} \mathrm{E}$, NE corner of Orog Lake, Bayankhongor; NS: 4 
ID 31: 1967.06.29. leg. Kaszab Z. $44.11^{\circ}$ N, $99.61^{\circ} \mathrm{E}, 100 \mathrm{~km} \mathrm{~S}$ of Somon Shine jinst, Bayankhongor; NS: 1

ID 32: 1967.06 .29 . leg. Kaszab Z. $44.52^{\circ} \mathrm{N}, 99.27^{\circ} \mathrm{E}$, Mt. Ongon Ulan, on the road to Shine Jinst, Bayankhongor; NS: 1

ID 33: 1967.07.01-02. leg. Kaszab Z. $44.35^{\circ} \mathrm{N}, 100.85^{\circ} \mathrm{E}, 26 \mathrm{~km}$ SE of Bayanlig, Bayankhongor; NS: 19

ID 34: 1990.05.21. leg. Fábián Gy., Hreblay M., Peregovits L., Ronkay G. $47.08^{\circ} \mathrm{N}, 104.08^{\circ} \mathrm{E}$, $64 \mathrm{~km} \mathrm{~W}$ of Erdenecant, Bulgan; NS: 1

ID 35: 1968.07.24. leg. Kaszab Z. $47.84^{\circ} \mathrm{N}, 104.31^{\circ} \mathrm{E}, 11 \mathrm{~km} \mathrm{~W}$ of Bayanuur, $\mathrm{S}$ part of Lake Bayan , Bulgan; NS: 5

ID 36: 1968.06.14. leg. Kaszab Z. $47.84^{\circ} \mathrm{N}, 104.31^{\circ} \mathrm{E}, 11 \mathrm{~km} \mathrm{~W}$ of Bayanuur, S part of Lake Bayan , Bulgan; NS: 7

ID 37: 1963.06.22. leg. Kaszab Z. $45.42^{\circ} \mathrm{N}, 108.41^{\circ} \mathrm{E}, 90 \mathrm{~km}$ SE of Csojren, Chara-Eireg, Dornogovi; NS: 1

ID 38: 1963.06.25. leg. Kaszab Z. $43.85^{\circ} \mathrm{N}, 110.03^{\circ} \mathrm{E}$, Argalant, Ulan-shire, Dornogovi; NS: 2

ID 39: 1963.06.22. leg. Kaszab Z. $44.37^{\circ} \mathrm{N}, 110.37^{\circ} \mathrm{E}$, Cagan Elis, $30 \mathrm{~km}$ ESE of Zuun Bayan, Dornogovi; NS: 10

ID 40: 1963.06.23. leg. Kaszab Z. $43.84^{\circ} \mathrm{N}, 110.43^{\circ} \mathrm{E}, 70 \mathrm{~km}$ SSE of Zuun Bayan, Dornogovi; NS: 3

ID 41: 1967.07.10. leg. Kaszab Z. $45.25^{\circ} \mathrm{N}, 105.24^{\circ} \mathrm{E}, 34 \mathrm{~km}$ SE from Somon Delgerkhangaj, Dundgovi; NS: 8

ID 42: 1964.06.16. leg. Kaszab Z. $46^{\circ} \mathrm{N}, 104.95^{\circ} \mathrm{E}, 70 \mathrm{~km} \mathrm{SW}$ of Somon Erdenedalai, Dundgovi; NS: 4

ID 43: 1967.06 .10 . leg. Kaszab Z. $45.21^{\circ} \mathrm{N}, 105.24^{\circ} \mathrm{E}$, Choot bulag, between Somon Khuld and Somon Delgerchangay, Dundgovi; NS: 43

ID 44: 1967.07.12. leg. Kaszab Z. $45.21^{\circ} \mathrm{N}, 105.24^{\circ} \mathrm{E}$, Choot bulag, between Somon Khuld and Somon Delgerchangay, Dundgovi; NS: 1

ID 45: 1964.06.05. leg. Z.Z.Syst. $45.73^{\circ} \mathrm{N}, 106.27^{\circ} \mathrm{E}$, Mandalgovi, Dundgovi; NS: 1

ID 46: 1967.07.04. leg. Kaszab Z. $45.17^{\circ} \mathrm{N}, 104.38^{\circ} \mathrm{E}, 140 \mathrm{~km}$ E of Bajanleg, Dundgovi; NS: 3

ID 47: 1965.06.08. leg. Z.Z.Syst. $45.14^{\circ} \mathrm{N}, 97.73^{\circ} \mathrm{E}$, Erdene district, Govi-Altai; NS: 1

ID 48: 1966.07.12. leg. Kaszab Z. $47.66^{\circ} \mathrm{N}, 93.75^{\circ} \mathrm{E}$, Baga Nuuryn Urd Els, NE corner of Lake Dooros, Govi-Altai; NS: 28

ID 49: 1966.06.26. leg. Kaszab Z. $45.75^{\circ} \mathrm{N}, 97.2^{\circ} \mathrm{E}$, Lake Beger, 4 km S of Somon Biger, GoviAltai; NS: 1

ID 50: 1966.06 .25 . leg. Kaszab Z. $45.75^{\circ} \mathrm{N}, 97.2^{\circ} \mathrm{E}$, Lake Beger, $10 \mathrm{~km}$ W of Somon Biger, Govi-Altai; NS: 1

ID 51: 1966.07.01. leg. Kaszab Z. $46.06^{\circ} \mathrm{N}, 93.98^{\circ} \mathrm{E}$, Between Bizj stream and Bodochijn stream, Govi-Altai; NS: 9

ID 52: 1966.07.14. leg. Kaszab Z. $46.71^{\circ} \mathrm{N}, 92.71^{\circ} \mathrm{E}$, Shujsijn Gobi, $20 \mathrm{~km}$ SE of Somon Chechmort, Govi-Altai; NS: 1

ID 53: 1965.07.27. leg. Z.Z.Syst. $45.74^{\circ} \mathrm{N}, 97.18^{\circ} \mathrm{E}$, Lake Beger, Govi-Altai; NS: 1

ID 54: 1965.07.27. leg. Z.Z.Syst. $45.74^{\circ} \mathrm{N}, 97.18^{\circ} \mathrm{E}$, Lake Beger, Govi-Altai; NS: 1

ID 55: 1966.06 .23 . leg. Kaszab Z. $46.54^{\circ} \mathrm{N}, 95.94^{\circ} \mathrm{E}$, SE corner of Schargyn Gobi, Govi-Altai; NS: 15

ID 56: 1966.06 .23 . leg. Kaszab Z. $46.54^{\circ} \mathrm{N}, 95.94^{\circ} \mathrm{E}$, SE corner of Schargyn Gobi, Govi-Altai; NS: 10

ID 57: 1966.06.24. leg. Kaszab Z. $45.75^{\circ} \mathrm{N}, 97.2^{\circ} \mathrm{E}$, Schargyn Gobi, Lake Beger, $10 \mathrm{~km}$ SW of Somon Chaliun, Govi-Altai; NS: 6 
ID 58: 1977.08.28-31. leg. Molnár G. $46.27^{\circ} \mathrm{N}, 95.26^{\circ} \mathrm{E}$, Somon Sharga, Govi-Altai; NS: 6

ID 59: 1977.08. leg. Haraszthy L. $46.34^{\circ} \mathrm{N}, 108.43^{\circ} \mathrm{E}$, Choir, Govisümber; NS: 5

ID 60: 1990.05.15. leg. Fábián Gy., Hreblay M., Peregovits L., Ronkay G. $45.8^{\circ}$ N, $92.83^{\circ} \mathrm{E}$, Dzsungar Gobi, $60 \mathrm{~km}$ E of Altay somon centre, Khovd; NS: 1

ID 61: 1966.07.05-06. leg. Kaszab Z. $45.74^{\circ} \mathrm{N}, 91.41^{\circ} \mathrm{E}, 10 \mathrm{~km}$ SSW of Somon Bulgan, Khovd; NS: 2

ID 62: 1966.07.04. leg. Kaszab Z. $46.07^{\circ} \mathrm{N}, 91.93^{\circ} \mathrm{E}, 10 \mathrm{~km}$ NW of Somon Üyench, Khovd; NS: 1

ID 63: 1966.07.06. leg. Kaszab Z. $46.5^{\circ}$ N, $91.54^{\circ}$ E, Mongol Altaj Mts., Uljasutajn stream, 45 km NNW of Somon Bulgan, Khovd; NS: 1

ID 64: 1966.07 .02 . leg. Kaszab Z. $49.01^{\circ} \mathrm{N}, 88.96^{\circ} \mathrm{E}$, Somon Altaj, Khovd; NS: 8

ID 65: 1965.08 .03 . leg. Z.Z.Syst. $47.48^{\circ} \mathrm{N}, 92.18^{\circ} \mathrm{E}$, Altan Teli, Khovd; NS: 1

ID 66: 1966.07.11-12. leg. Kaszab Z. $47.79^{\circ} \mathrm{N}, 92^{\circ} \mathrm{E}$, Yamatin Dolon, $40 \mathrm{~km}$ N of Somon Manchan, SW corner of Lake Char Us, Khovd; NS: 11

ID 67: 1990.05.14. leg. Fábián Gy., Hreblay M., Peregovits L., Ronkay G. $43.78^{\circ}$ N, $99.88^{\circ}$ E, Naran Bulag, Ömnögovi; NS: 1

ID 68: 1990.05.14. leg. Fábián Gy., Hreblay M., Peregovits L., Ronkay G., Ronkay L. $43.78^{\circ}$ N, 99.88² E, Naran Bulag, Ömnögovi; NS: 5

ID 69: 1964.06.17. leg. Kaszab Z. $44.68^{\circ} \mathrm{N}, 104.05^{\circ} \mathrm{E}, 1 \mathrm{~km}$ N of Mandal-Ovoo, Ömnögovi; NS: 7

ID 70: 1964.06 .19 . leg. Kaszab Z. $43.53^{\circ} \mathrm{N}, 104.48^{\circ} \mathrm{E}, 10 \mathrm{~km} \mathrm{~S}$ of Somon Bulgan, Ömnögovi; NS: 1

ID 71: 1967.06.22. leg. Kaszab Z. $43.09^{\circ} \mathrm{N}, 100.55^{\circ} \mathrm{E}, 100 \mathrm{~km} \mathrm{~W}$ of Ovot Chuural Border Control, Ömnögovi; NS: 2

ID 72: 1967.06.18. leg. Kaszab Z. $43.43^{\circ}$ N, $102.06^{\circ}$ E, 18 km SW of Somon Sevrei, Ömnögovi; NS: 2

ID 73: 1964.06 .19 . leg. Kaszab Z. $43.86^{\circ} \mathrm{N}, 104.46^{\circ} \mathrm{E}, 25 \mathrm{~km}$ N of Somon Bulgan, Ömnögovi; NS: 2

ID 74: 1967.06.23. leg. Kaszab Z. $42.78^{\circ} \mathrm{N}, 99.47^{\circ} \mathrm{E}, 40 \mathrm{~km}$ E of Talyn Bilgech bulag source, between Mt Ul and Mt. Cagan Bogd, Ömnögovi; NS: 1

ID 75: 1964.06.20. leg. Kaszab Z. $44.19^{\circ} \mathrm{N}, 103.61^{\circ} \mathrm{E}, 60 \mathrm{~km}$ W of Somon Bulgan, Ömnögovi; NS: 1

ID 76: 1965.06.15. leg. Z.Z.Syst. $43.66^{\circ} \mathrm{N}, 100.43^{\circ} \mathrm{E}$, Altan Mts., Ömnögovi; NS: 1

ID 77: 1967.07.06-07. leg. Kaszab Z. 44.13 N, 103.72E, Bayan Zag, Ömnögovi; NS: 6

ID 78: 1971.07 .04 . leg. Beregi Zs. $43.61^{\circ} \mathrm{N}, 104.51^{\circ} \mathrm{E}, 5 \mathrm{~km}$ NNE of Dalanzadgad, Ömnögovi; NS: 3

ID 79: 1967.06.18. leg. Kaszab Z. $43.44^{\circ} \mathrm{N}, 101.52^{\circ} \mathrm{E}$, SW corner og Lake Dund Gol, Ömnögovi; NS: 1

ID 80: 1967.06 .14 . leg. Kaszab Z. $43.36^{\circ} \mathrm{N}, 104.43^{\circ} \mathrm{E}$, Mt. Gurban Sajchan, $10 \mathrm{~km}$ W of Somon Khürmen, Ömnögovi; NS: 7

ID 81: 1967.06.14. leg. Kaszab Z. $43.47^{\circ}$ N, $104.5^{\circ}$ E, Between Mt. Gurban Sajchan and Somon Bayandalai, Ömnögovi; NS: 16

ID 82: 1967.07.07. leg. Kaszab Z. $43.65^{\circ} \mathrm{N}, 104.53^{\circ} \mathrm{E}, 10 \mathrm{~km}$ NNE of Dalanzadgad, Ömnögovi; NS: 3

ID 83: 1967.06.19. leg. Kaszab Z. $43.56^{\circ} \mathrm{N}, 104.47^{\circ} \mathrm{E}$, Nojon nuruun Mts., between Dond Gol and Somon Noyon, Ömnögovi; NS: 1

ID 84: 1967.06.20. leg. Kaszab Z. $43.1^{\circ} \mathrm{N}, 99.36^{\circ} \mathrm{E}$, Nojon nuruun Mts., Ovot Chuural Border Control, Ömnögovi; NS: 9 
ID 85: 1967.06.17. leg. Kaszab Z. $43.49^{\circ}$ N, $102.11^{\circ}$ E, Mt. Sevrei, $10 \mathrm{~km}$ SW of Somon Sevrei, Ömnögovi; NS: 4

ID 86: 1967.06.15. leg. Kaszab Z. $43.03^{\circ} \mathrm{N}, 103.8^{\circ} \mathrm{E}, 14 \mathrm{SW}$ of Somon Bayandalai, Ömnögovi; NS: 15

ID 87: 1967.07.05. leg. Kaszab Z. $42.8^{\circ} \mathrm{N}, 99.96^{\circ} \mathrm{E}$, Somon Bulgan, Talyn bulag source, Ömnögovi; NS: 4

ID 88: 1967.07.05. leg. Kaszab Z. $43.62^{\circ} \mathrm{N}, 104.05^{\circ} \mathrm{E}, 30 \mathrm{~km} \mathrm{~W}$ of Somon Bulgan, Ömnögovi; NS: 9

ID 89: 1967.07.04-05. leg. Kaszab Z. $43.62^{\circ} \mathrm{N}, 104.35^{\circ} \mathrm{E}, 7 \mathrm{~km} \mathrm{~W}$ of Somon Bulgan, Ömnögovi; NS: 13

ID 90: 1967.06.12. leg. Kaszab Z. $43.96^{\circ} \mathrm{N}, 104.95^{\circ}$ E, Tachijn Schar Mts., between Somon Tsogt Ovoo and Dalanzadgad, Ömnögovi; NS: 1

ID 91: 1967.07.08-09. leg. Kaszab Z. $43.96^{\circ} \mathrm{N}, 104.95^{\circ}$ E, Tachijn Schar Mts., between Somon Tsogt Ovoo and Dalanzadgad, Ömnögovi; NS: 30

ID 92: 1965.06.16. leg. Z.Z.Syst. $43.66^{\circ} \mathrm{N}, 100.43^{\circ} \mathrm{E}$, Altan Mts., Ömnögovi; NS: 2

ID 93: 1967.06.16. leg. Kaszab Z. $43.31^{\circ} \mathrm{N}, 102.98^{\circ} \mathrm{E}, 58 \mathrm{~km}$ WSW of Somon Bayandalai, E part of Mt. Zöölön , Ömnögovi; NS: 1

ID 94: 1965.06.03. leg. Z.Z.Syst. $44.13^{\circ} \mathrm{N}, 103.72^{\circ} \mathrm{E}$, Bayan Zag, Ömnögovi; NS: 1

ID 95: 1964.06.23. leg. Kaszab Z. $45.03^{\circ} \mathrm{N}, 101.58^{\circ} \mathrm{E}, 20 \mathrm{~km}$ SE of Somon Baruun Bajanulaan, Övörhkhangai; NS: 5

ID 96: 1964.06.22. leg. Kaszab Z. $45.63^{\circ} \mathrm{N}, 100.53^{\circ} \mathrm{E}, 50 \mathrm{~km} \mathrm{NW}$ of Somon Bogd, Övörhkhangai; NS: 2

ID 97: 1964.06.21. leg. Kaszab Z. 44.36 N, $102.88^{\circ}$ E, Mt. Arc Bogd, 20 km S of Somon Chovd, Övörhkhangai; NS: 1

ID 98: 1965.08.03-05. leg. Kaszab Z. $45.67^{\circ} \mathrm{N}, 112.68^{\circ}$ E, Ongon Elis, $10 \mathrm{~km}$ S of Somon Chongor, Sükhbaatar; NS: 1

ID 99: 1965.08 .06 . leg. Kaszab Z. $45.27^{\circ} \mathrm{N}, 113.85^{\circ} \mathrm{E}$, Molzog elis, $2 \mathrm{~km}$ S of Somon Dariganga, Sükhbaatar; NS: 2

ID 100: 1965.08.03-05. leg. Kaszab Z. $45.25^{\circ} \mathrm{N}, 103.04^{\circ}$ E, Ongon Elis, $10 \mathrm{~km} \mathrm{~S}$ of Somon Chongor, Sükhbaatar; NS: 24

ID 101: 1965.08.05. leg. Kaszab Z. $45.03^{\circ} \mathrm{N}, 113.15^{\circ} \mathrm{E}, 5 \mathrm{~km}$ S of Somon Ongon, Sükhbaatar; NS: 5

ID 102: 1965 leg. Kubiak H., Z.Z.Syst. $47.04^{\circ}$ N, $106.22^{\circ}$ E, Zorgol Khargan Mts., Töv; NS: 3

ID 103: 1965.06.03. leg. Z.Z.Syst. $47.04^{\circ} \mathrm{N}, 106.55^{\circ} \mathrm{E}$, Zorgol Khargan Mts., Töv ; NS: 1

ID 104: 1968.07.09. leg. Kaszab Z. $49.51^{\circ} \mathrm{N}, 92.22^{\circ} \mathrm{E}, 10 \mathrm{~km}$ NE of Somon Naranbulag, Uvs; NS: 3

ID 105: 1968.06.25. leg. Kaszab Z. 50.01, $93.84^{\circ}$ E, Lake Bag, 6 km N of Somon Züüngovi, Uvs; NS: 1

ID 106: 1968.07.10. leg. Kaszab Z. $49.32^{\circ} \mathrm{N}, 93.25^{\circ} \mathrm{E}$, NE corner of Lake Chjargas, $80 \mathrm{~km}$ SE of Somon Naranbulag, Uvs; NS: 7

\section{LACERTIDAE}

Eremias argus Peters, 1869

ID 120: 1970.07.23. leg. Beregi Zs. $47.29^{\circ} \mathrm{N}, 114.18^{\circ} \mathrm{E}, 70 \mathrm{~km}$ SW of Cojbalsan, Dornod; NS: 2

ID 121: 1963.06.27. leg. Kaszab Z. $44.69^{\circ} \mathrm{N}, 110.13^{\circ} \mathrm{E}, 20 \mathrm{~km} \mathrm{~S}$ of Sainschand, Dornogovi; NS: 1 
ID 122: 1963.06.30. leg. Kaszab Z. $46.37^{\circ} \mathrm{N}, 108.64^{\circ} \mathrm{E}, 60 \mathrm{~km}$ NW of Chara-Eireg, Choir, Dornogovi; NS: 1

ID 123: 1967.06.11. leg. Kaszab Z. $45.48^{\circ} \mathrm{N}, 105.42^{\circ} \mathrm{E}$, Mt. Delgerkhangaj, $6 \mathrm{~km}$ S of Somon

Delgerkhangaj, Dundgovi; NS: 3

ID 124: 1965.07.24. leg. Z.Z.Syst. $45.75^{\circ} \mathrm{N}, 97.2^{\circ} \mathrm{E}$, Lake Beger, Biger, Govi-Altai; NS: 1

ID 125: 1965.08 .04 . leg. Z.Z.Syst. $47.48^{\circ} \mathrm{N}, 92.18^{\circ} \mathrm{E}$, Altan Teli, Khovd; NS: 1

ID 126: 1965.08 .04 . leg. Z.Z.Syst. $47.48^{\circ} \mathrm{N}, 92.18^{\circ} \mathrm{E}$, Altan Teli, Khovd; NS: 1

ID 127: 1965.08.06. leg. Z.Z.Syst. $43.66^{\circ} \mathrm{N}, 100.43^{\circ} \mathrm{E}$, Altan Mts., Ömnögovi; NS: 1

ID 128: 1965.06 .05 . leg. Z.Z.Syst. $43.66^{\circ} \mathrm{N}, 100.43^{\circ} \mathrm{E}$, Altan Mts., Ömnögovi; NS: 1

ID 129: 1964.08.01. leg. Z.Z.Syst. $44.13^{\circ} \mathrm{N}, 103.72^{\circ} \mathrm{E}$, Bayan Zag, Bulgan, Ömnögovi; NS: 3

ID 130: 1966.07.06. leg. Kaszab Z. 46.5N, $91.54^{\circ} \mathrm{E}$, Mongol Altaj Mts., Uljasutajn gol, $45 \mathrm{~km}$ SE of Somon Bulgan, Khovd; NS: 1

ID 131: 1966.07.06. leg. Kaszab Z. 46.5N, 91.54E, Mongol Altaj Mts., Uljasutajn gol, 45 km NE of Somon Bulgan, Khovd; NS: 1

ID 132: 1967.06.19. leg. Kaszab Z. 43.1 ${ }^{\circ}$ N, $101.71^{\circ} \mathrm{E}$, Nojon Mts., between Dundgol and Somon Nojon, SE from Lake Sós, Ömnögovi; NS: 1

ID 133: 1965.08.05. leg. Kaszab Z. $45.3^{\circ} \mathrm{N}, 113.13^{\circ} \mathrm{E}, 5 \mathrm{~km}$ S of Somon Chongor, Sükhbaatar; NS: 3

ID 134: $1965.08 .03-05$. leg. Kaszab Z. $45.67^{\circ} \mathrm{N}, 112.68^{\circ}$ E, Ongon Elis, $10 \mathrm{~km} \mathrm{~S}$ of Somon Chongor, Sükhbaatar; NS: 2

ID 135: 1972.08.02. leg. Mészáros F. $46.94^{\circ} \mathrm{N}, 113.79^{\circ} \mathrm{E}, 100 \mathrm{~km} \mathrm{NW}$ of Baruun Urt, Sükhbaatar; NS: 1

ID 136: 1970.09.24. leg. Beregi Zs. $46.94^{\circ} \mathrm{N}, 113.79^{\circ} \mathrm{E}, 100 \mathrm{~km}$ SW of Cojbalsan, Sükhbaatar; NS: 1

ID 137: 1972.08.02. leg. Mészáros F. $46.94^{\circ} \mathrm{N}, 113.79^{\circ} \mathrm{E}, 100 \mathrm{~km}$ NW of Baruun Urt, Sükhbaatar; NS: 2

ID 138: 1970.07 .07$. leg. Beregi Zs. $46.94^{\circ} \mathrm{N}, 113.79^{\circ} \mathrm{E}$, Lake Aren, $100 \mathrm{~km}$ SW of Cojbalsan, Sükhbaatar; NS: 1

ID 139: 1976.08 .12 . leg. Kiss I. $48.06^{\circ} \mathrm{N}, 114.46^{\circ} \mathrm{E}$, Cojbalsan, Sükhbaatar; NS: 1

ID 140: 1968.08 .24 . leg. Kaszab Z. $47.84^{\circ} \mathrm{N}, 104.31^{\circ} \mathrm{E}$, S side of Lake Bajan, $11 \mathrm{~km}$ W of Somon Bajanuur, Zavkhan; NS: 18

ID 141: 1966.06.18. leg. Kaszab Z. $47.83^{\circ} \mathrm{N}, 104.17^{\circ} \mathrm{E}, 20 \mathrm{~km}$ W of Somon Bajanuur, Zavkhan; NS: 1

Eremias arguta (Pallas, 1773)

ID 142: 1990.05.15. leg. Fábián Gy., Hreblay M., Peregovits L., Ronkay G. $45.8^{\circ} \mathrm{N}, 92.83^{\circ} \mathrm{E}$, Dzsungar Gobi, 60 km E of Altay somon centre, Khovd; NS: 1

Eremias multiocellata Günther, 1872

ID 143: 1967.06.30. leg. Kaszab Z. $45.39^{\circ} \mathrm{N}, 100.02^{\circ} \mathrm{E}$, Mt. Jinst, $50 \mathrm{~km}$ E of Somon Schine Jinst, Bayankhongor; NS: 1

ID 144: 1963.06.25. leg. Kaszab Z. $43.91^{\circ} \mathrm{N}, 110.39^{\circ} \mathrm{E}, 65 \mathrm{~km}$ SE of Zuun Bajan, Argalant, Dornogovi; NS: 1

ID 145: 1963.06.24. leg. Kaszab Z. $43.71^{\circ} \mathrm{N}, 110.51^{\circ} \mathrm{E}, 80 \mathrm{~km}$ SE of Zuun Bajan, Argalant, Dornogovi; NS: 2

ID 146: 1963.06 .22 . leg. Kaszab Z. $45.42^{\circ} \mathrm{N}, 108.41^{\circ} \mathrm{E}$, Chara-Eireg, $90 \mathrm{~km}$ SE from Csojr, Dornogovi; NS: 1

ID 147: 1963.06.24. leg. Kaszab Z. $43.77^{\circ} \mathrm{N}, 110.47^{\circ} \mathrm{E}, 75 \mathrm{~km}$ SE of Zuun Bajan, Argalant, Dornogovi; NS: 2 
ID 148: 1967.07.10. leg. Kaszab Z. 45.31N, $105.67^{\circ} \mathrm{E}, 34 \mathrm{~km}$ SE from Somon Delgerkhangaj, Dundgovi; NS: 1

ID 149: 1967.06.10. leg. Kaszab Z. $45.21^{\circ} \mathrm{N}, 105.24^{\circ} \mathrm{E}, 38 \mathrm{~km}$ NE of Delgerkhangaj, Choot bulag, Dundgovi; NS: 49

ID 150: 1966.07.12. leg. Kaszab Z. $47.64^{\circ} \mathrm{N}, 93.73^{\circ} \mathrm{E}$, Baga Nuuryn Urd Els, SE corner of Lake Dooros, Govi-Altai; NS: 4

ID 152: 1966.06.26. leg. Kaszab Z. $45.75^{\circ} \mathrm{N}, 97.2^{\circ} \mathrm{E}$, Lake Beger, $4 \mathrm{~km}$ S of Somon Beger, Govi-Altai; NS: 1

ID 156: 1964.08.01. leg. Z.Z.Syst. $44.13^{\circ} \mathrm{N}, 103.72^{\circ} \mathrm{E}$, Bayan Zag, Bulgan, Ömnögovi; NS: 1

ID 157: 1990.05.13. leg. Peregovits L. \& al. 43.01 N, 101.21ํㅡ, Nojon Mts., $22 \mathrm{~km}$ SE of Gurvantes, Ömnögovi; NS: 1

ID 158: 1967.07.04-05. leg. Kaszab Z. $43.62^{\circ} \mathrm{N}, 104.35^{\circ} \mathrm{E}, 7 \mathrm{~km}$ W of Somon Bulgan, Ömnögovi; NS: 6

ID 159: 1967.06 .14 . leg. Kaszab Z. $43.36^{\circ} \mathrm{N}, 104.43^{\circ} \mathrm{E}$, Mt. Gurban Sajchan, $10 \mathrm{~km}$ W of Somon Khürmen, Ömnögovi; NS: 1

ID 160: 1967.06.12. leg. Kaszab Z. $43.96^{\circ}$ N, $104.95^{\circ}$ E, Mt. Tachilga, Dalanzadgad, Ömnögovi; NS: 38

ID 161: 1967.07.08-09. leg. Kaszab Z. $43.96^{\circ}$ N, $104.95^{\circ}$ E, Mt. Tachilga, Dalanzadgad, Ömnögovi; NS: 1

ID 162: 1968.07.09. leg. Kaszab Z. $49.51^{\circ} \mathrm{N}, 92.22^{\circ} \mathrm{E}, 10 \mathrm{~km}$ NW of Somon Naranbulag, Uvs; NS: 2

ID 163: 1968.07.10. leg. Kaszab Z. $49.32^{\circ} \mathrm{N}, 93.25^{\circ} \mathrm{E}$, NE corner of Lake Chjargas, $80 \mathrm{~km}$ SE of Somon Naranbulag, Uvs; NS: 2

Eremias przewalskii (Strauch, 1876)

ID 164: 1964.06.17. leg. Kaszab Z. $44.68^{\circ} \mathrm{N}, 104.05^{\circ} \mathrm{E}, 1 \mathrm{~km}$ N of Mandal-Ovoo, Ömnögovi; NS: 13

ID 165: 1967.06.15. leg. Kaszab Z. $43.03^{\circ} \mathrm{N}, 103.8^{\circ} \mathrm{E}, 14 \mathrm{~km}$ SW of Somon Bayandalai, Ömnögovi; NS: 12

ID 166: 1967.07.05. leg. Kaszab Z. $43.62^{\circ} \mathrm{N}, 104.35^{\circ} \mathrm{E}, 30 \mathrm{~km} \mathrm{~W}$ of Somon Bulgan, Ömnögovi; NS: 7

ID 167: 1964.08.01. leg. Z.Z.Syst. $44.13^{\circ} \mathrm{N}, 103.72^{\circ} \mathrm{E}$, Bayan Zag, Ömnögovi; NS: 5

ID 168: 1967.07.05. leg. Kaszab Z. $42.8^{\circ} \mathrm{N}, 99.96^{\circ} \mathrm{E}$, Somon Bulgan, Talyn bulag source, Ömnögovi; NS: 4

ID 169: 1967.06 .18 . leg. Kaszab Z. $43.44^{\circ} \mathrm{N}, 101.52^{\circ} \mathrm{E}$, SW side of Lake Dund gol, Gurvantes, Ömnögovi; NS: 4

Eremias dzungarica Orlova, Poyarkov, Chirikova, Nazarov, Munkhbaatar, Munkhbayar et Terbish, 2017

ID 151: 1966.07.14. leg. Kaszab Z. $46.71^{\circ} \mathrm{N}, 92.71^{\circ} \mathrm{E}$, Chujsiju-Gobi, $20 \mathrm{~km}$ SE of Somon Chechmort, Govi-Altai; NS: 2

ID 153: 1966.07 .02 leg. Kaszab Z. $46.08^{\circ} \mathrm{N}, 92.05^{\circ} \mathrm{E}, 3 \mathrm{~km} \mathrm{~N}$ of Somon Uenc, in the valley of River Uenc, Khovd; NS: 2

ID 154: 1990.05.15. leg. Fábián Gy., Hreblay M., Peregovits L., Ronkay G. $45.8^{\circ} \mathrm{N}, 92.83^{\circ} \mathrm{E}$, Dzsungar Gobi, $60 \mathrm{~km}$ E of Altay somon centre, Khovd; NS: 2

ID 155: 1966.07.01. leg. Kaszab Z. $46^{\circ} \mathrm{N}, 94.03^{\circ} \mathrm{E}$, Somon Altaj, on the left side of River Bodonchi, Khovd; NS: 3 


\section{COLUBRIDAE}

Elaphe dione (Pallas, 1773)

ID 170: 1964.07.07. leg. Kaszab Z. $48.85^{\circ} \mathrm{N}, 106.34^{\circ} \mathrm{E}, 5 \mathrm{~km} \mathrm{~W}$ of Zuun Chara, Töv; NS: 1

ID 171: 1967.07.10-11. leg. Kaszab Z. $45.18^{\circ} \mathrm{N}, 104.61^{\circ} \mathrm{E}$, Mt. Delgerkhangaj, 6 km S of Somon Delgerkhangaj, Dundgovi; NS: 1

ID 172: 1965.08. leg. Kubiak H., Z.Z.Syst. $43.69^{\circ} \mathrm{N}, 100.92^{\circ} \mathrm{E}$, Nemegt Valley, Altan Ula Mts., Gurban Saikhan, Ömnögovi; NS: 2

ID 173: 1978.08. leg. Pertényi Z. $47.61^{\circ} \mathrm{N}, 110.25^{\circ} \mathrm{E}, 60 \mathrm{~km}$ NNW of Öndör han, Khentii; NS: 1

ID 174: 1973.08.10. leg. Pertényi Z. $50.19^{\circ} \mathrm{N}, 106.24^{\circ} \mathrm{E}, 20 \mathrm{~km} \mathrm{~S}$ of Suchebaator, Sükhbaatar; NS: 1

\section{VIPERIDAE}

Gloydius halys (Pallas, 1776)

ID 175: 1967.07.01-02. leg. Kaszab Z. 44.35 N, 100.85E, 26 km SE of Bayanlig, Bayankhongor; NS: 1

ID 176: 1967.06 .30 . leg. Kaszab Z. $45.04^{\circ} \mathrm{N}, 100.24^{\circ} \mathrm{E}$, Mt. Zinat, $50 \mathrm{~km}$ E of Shinejinst, Bayankhongor; NS: 1

ID 177: 1968.07.24. leg. Kaszab Z. $47.84^{\circ} \mathrm{N}, 104.31^{\circ} \mathrm{E}, 11 \mathrm{~km} \mathrm{~W}$ of Bayanuur, S part of Lake Bayan , Bulgan; NS: 2

ID 178: 1963.06.24. leg. Kaszab Z. $43.79^{\circ} \mathrm{N}, 110.51^{\circ} \mathrm{E}, 80 \mathrm{~km}$ SSE of Zuun Bajan, Argalant, Dornogovi; NS: 1

ID 179: 1968.06.19. leg. Kaszab Z. $49.98^{\circ}$ N, $99.54^{\circ} \mathrm{E}, 60 \mathrm{~km}$ WNW of Mörön, Hövsgöl; NS: 1

ID 180: 1980.07.01. leg. Perregi Zs. $47.63^{\circ} \mathrm{N}, 110.18^{\circ} \mathrm{E}, 65 \mathrm{NW}$ of Öndör han, Khentii; NS: 1

ID 181: 1979.09.03. leg. Perregi Zs. $47.72^{\circ} \mathrm{N}, 110^{\circ} \mathrm{E}, 80 \mathrm{NW}$ of Öndör han, Khentii; NS: 1

ID 182: 1967.07.04-05. leg. Kaszab Z. $43.62^{\circ} \mathrm{N}, 104.35^{\circ} \mathrm{E}, 7 \mathrm{~km}$ W of Somon Bulgan, Ömnögovi; NS: 1

ID 183: 1970.08 .18 . leg. Jámbor Á. $46.9^{\circ} \mathrm{N}, 113.81^{\circ} \mathrm{E}, 100 \mathrm{~km} \mathrm{SW}$ of Cojbalsan Somon Bajanuur, Sükhbaatar; NS: 1

ID 184: 1965.08 .25 . leg. Kaszab Z. $47.62^{\circ} \mathrm{N}, 108.04^{\circ} \mathrm{E}, 60 \mathrm{~km}$ E of Ulanbator, at the Tuul River, Töv; NS: 1 